\title{
Türkiye ve Seçilmiş Ülkelerde Mevduat Kabul Eden Kuruluşların Finansal Sağlamlık Göstergelerinin Entropi ve Edas Yöntemi ile Değerlendirilmesi
}

\author{
Hüseyin SELIMLER ${ }^{1}$ \\ Mehmet Mete KARADAĞ $\breve{G}^{2}$
}

ÖZ

Finansal Sağlamlık Göstergeleri (Financial Soundness Indicators: FSI), finansal kurumlarla piyasaların ve bunların şirket ve hane halk1 benzerlerinin sağlık ve sağlamlığını izlemek için derlenen göstergelerdir. $\mathrm{Bu}$ çalışmada, IMF tarafindan oluşturulan ve mevduat kabul eden kuruluşlar için temel set olarak kabul edilen 12 finansal sağlamlık göstergesi dikkate alınmıştır. Türkiye ile 2004 y1lı ve sonrası Avrupa Birliği'ne üye olan, aday olan ve potansiyel aday toplam 19 ülkeye ait 2018 verileri kullanılmıştır. Çalışmada, 12 temel kriterin ağırlıkları Entropi yöntemi ile tespit edilmiş, daha sonra EDAS yöntemi ile ülkelerin finansal sağlamlık göstergelerine göre performans sıralaması yapılmıştır. İlk üç sırayı Romanya, Macaristan ve Polonya alırken, Türkiye 7. sırada yer almıştır.

Anahtar Kelimeler: Finansal Sağlamlı Göstergesi, Avrupa Birliği, Performans, EDAS, Entropi Yöntemi, Banka

JEL Sinıflamasi: G15, G17, G21,

\footnotetext{
${ }^{1}$ Doç. Dr., İstanbul Aydın Üniversitesi, İ̈BF, Ekonomi ve Finans Bölümü, huseyinselimler@aydin.edu.tr

${ }^{2}$ Dr. Öğretim Üyesi, İstanbul Aydın Üniversitesi, ABMYO İşletme Programı, metekaradag@aydin.edu.tr

Doi Num: 10.17932/IAU.FCPE.2015.010/fcpe_v06i1005
} 


\title{
Evaluation of Financial Soundness Indicators of Deposit Institutions by ENTROPY and EDAS Methods in Turkey and Selected
}

\section{Countries}

\begin{abstract}
Financial Soundness Indicators (FSI) are indicators compiled to monitor the health and soundness of financial institutions and markets and their corporate and household counterparts. In this study, 12 financial soundness indicators created by the IMF and accepted as the basic set for institutions accepting deposits are taken into consideration. The study was carried out by using the 2018 year-data of total 19 countries including the candidates and potential candidates of the EU and the members of the EU in 2004 and the following years, and Turkey. In this study, weights of 12 main criteria were determined by Entropy method and then EDAS method was used to execute performance ranking according to financial soundness indicators of selected countries. The first three places in Romania, Hungary and Poland, while Turkey was ranked 7 th.
\end{abstract}

Keywords: Financial Soundness Indicators, European Union, Performance, EDAS, Entropi Method, Bank

JEL Classification: G15, G17, G21,

\section{GIRIŞ}

Finansal istikrar, finansal sistemin parçası olan ekonomik işlevlerin beklenmeyen bir durum karşısında ortaya çıkabilecek şoklara karşı dayanıklılığını ve sağlıklı şekilde sürdürülmesini ifade etmektedir (TCMB,2014:2). Böylece, sağlıklı ve güçlü finansal sistemler fonları verimli yatırım projelerine tahsis ederek ve ödeme hizmetleri sağlayarak ekonomik faaliyet ve refah seviyesinin artmasina katkıda bulunurlar. Ancak mevcut deneyimler göstermiştir ki, finansal sistemler finansal faaliyetlere zarar veren ve ekonomiye çok büyük tutarlı ve geniş çaplı maliyetler yükleyen istikrarsızlı ve krizlere de eğilimlidirler. (IMF,2006:1) Finansal sistemde en büyük paya bankalar sahip olduğundan, bankaların sağlamlığı da ayrı bir öneme sahiptir. 
Lindgren, Garcia ve Saal (1996)'e göre banka sağlamlığı, çoğunlukla olumsuz olaylara dayanabilme becerisini ifade etmek için kullanılan bir kavramdır. Sağlam bir bankacılık sistemi ise bankaların çoğunun yeterli ödeme gücüne sahip oldukları ve muhtemelen de bu şekilde kalacakları bir sistemi ifade etmektedir (Lindgren vd., 1996:9). Sağlıklı bir finansal sistemin ekonomik büyüme ve gelişme üzerindeki rolü büyüktür. Finansal sistemlerin etkin bir şekilde işlemediği, finansal istikrarsızlığın olduğu durumlarda ise verimli yatırım projelerine kaynakların aktarılması güçleşecek, ekonomik faaliyetler gerileyecek; sonuçta hem finansal piyasalar hem de genel olarak ekonominin bütününde geniş çaplı olumsuz sonuçlar meydana gelebilecektir.

Bankacılık sektörü kaynaklı bir kriz hem kendisi hem de diğer sektörleri önemli ölçüde etkilemektedir. $\mathrm{Bu}$ nedenle, bankacılık sektörünün sağlamlığını ölçecek çalışmalar, endeks geliştirme çalışmaları, düzenleyici ve denetleyici kurumların finansal sağlamlık göstergesi olarak kabul edebileceği oranlar oluşturulmaya çalışılmaktadır. Finansal sağlamlık göstergeleri de bankacılık sektörünün genel sağlamlık durumunu izlemek için yararlı araçlar arasındadır (Navajas and Thegeya, 2013:3).

Ülkelerin mevcut verileri 2018 y1lına ait olup, entropi yöntemi ile ağırlık belirlenmiş ve EDAS yöntemi ile sıralama yapılmıştır. Farklı bir yıl verilerinin dikkate alınması, sübjektif olarak uzman görüşü ile ağırlıkların belirlenmesi, farklı bir Çok Kriterli Karar Verme yöntemi kullanılması durumunda farklı sıralamalar oluşabilir.

\section{FİNANSAL SAĞLAMLIK GÖSTERGELERİ}

Finansal Sağlamlık Göstergeleri (Financial Soundness Indicators: FSI), hem finansal kurumlar hakkında toplu bilgileri hem de finansal kurumların faaliyet gösterdiği piyasaları temsil eden, bunların sağlık ve sağlamlığını izlemek için derlenen göstergeleri içermekte olup (Sundararajan vd., 2002:2), ulusal finans sistemlerinin finansal risklerini ve kırılganlıklarını izlemek için daha iyi veri ve araçlara olan ihtiyaçtan çıkmıştır (Jose and Georgiou, 2009:277). 
1999 yılında Uluslararası Para Fonu (IMF) ve Dünya Bankas1 (Worldbank) tarafindan ülkelerin finansal sistemlerini kapsamlı ve derinlemesine analiz etmek için Finansal Sektör Değerlendirme Programı (The Financial Sector Assessment Program (FSAP) oluşturulmuştur. FSAP, iki temel bileşeni içermektedir: Birincisi, Uluslararası Para Fonu (International Money Fund-IMF)'nun sorumluluğunda olan finansal istikrar değerlendirmesi; ikincisi, Dünya Bankası'nın (Worldbank - WB) sorumluluğunda olan finansal gelişmenin değerlendirmesidir. Bugüne kadar, üye ülkelerin dörtte birinden fazlası değerlendirmeye tabi tutulmuştur (IMF, 2017). Amac1, ülkelerin finansal sistemlerinin zayıflıklarının saptanması ve gerekli tedbirlerin alınmasına katkıda bulunmaktır.

1990'lı yılların sonlarında yaşanan Asya finansal krizi ve 2008'deki küresel finansal kriz nedeniyle finansal sektörün finansal gösterge setlerine dayalı olarak güçlü ve zayıf yanlarının değerlendirmesi giderek daha da önem kazanmıştır. Bu değerlendirmeye finansal sektörde bir kırılganlığa yol açmak suretiyle finansal krizlere neden olabilecek potansiyel sorunların tanımlanması için de ihtiyaç duyulmuştur (Asian Development Bank, 2015:vii).

Ülkelerin finansal kuruluşlarının sağlı̆g 1 ve sağlamlığına dair bir fikir sağlamak amacı ile IMF Yürütme Kurulu tarafindan Haziran 2001'de temel ve önerilen finansal sağlamlık gösterge listesi oluşturulmuştur. Finansal sağlamlık göstergelerinin IMF üyeleri tarafından derlenmesi için kavram ve tanımlar konusunda standart bir referans oluşturma amaciyla da IMF tarafindan Finansal Sağlamlık Göstergeleri Derleme Kılavuzu hazırlanmıştır (IMF, 2015).

Finansal sağlamlık göstergeleri, finansal sistemlerin güçlü ve kırılgan yönlerini değerlendirme ve izlemeye yardımcı olmak amacıyla oluşturulmuş olup (IMF, 2006:11), bu göstergeler, makro ihtiyatı analizi desteklemek amacıyla hesaplanmakta ve yaygınlaştırılmaktadır (IMF, 2006:1). Makroihtiyati analiz, bir bütün olarak finansal sistemde ortaya çıkan riskleri tanımlamaya odaklanmaktadır (IMF, 2006:2). Bu göstergelerden yararlanılmak suretiyle finansal sistemin sağlığı ölçülebilir 
(Navajas and Thegeya,2013:3), finansal riskler gözlemlenerek finansal krizleri engellemek için gerekli tedbirler alınabilir.

Finansal sağlamlık göstergeleri temel seti; sermaye yeterliliği, aktif kalitesi, getiriler ve kârlılık, likidite ve piyasa riskine olan duyarlılık olmak üzere 5 gruptur. Mevduat kabul eden kuruluşlar dışında, diğer finansal kuruluşlar, finansal olmayan kuruluşlar, hane halkları, piyasa likiditesi ve gayrimenkul piyasaları ile ilgili 27 önerilen set ayrıca yer almaktadır. Zorunlu setleri ülkeler derlemek zorundadırlar, önerilen setleri ise kendi durumlarına göre seçebilirler. IMF'nin mevduat kabul eden kuruluşlar için 12 göstergeden oluşan temel finansal sağlamlık göstergeleri Tablo 1'de yer almaktadır:

Tablo 1: IMF Finansal Sağlamlık Göstergeleri: Temel Set

\begin{tabular}{ll}
\hline & Göstergeler \\
\hline Sermaye Yeterliliği & Yasal Öz kaynak / Risk Ağırlıklı Varlıklar \\
& Birinci Kuşak Sermaye / Risk Ağırlıklı Varlıklar \\
& Net Takipteki Alacaklar / Sermaye \\
& Takipteki Alacaklar / Toplam Krediler \\
Aktif Kalitesi & Kredilerin Sektörel Dağılımı \\
& Net Kâr / Toplam Aktifler \\
Getiriler ve Karlılık & Net Kâr / Öz kaynaklar \\
& Faiz Marjı / Toplam Gelir \\
& Faiz Dışı Giderler / Toplam Gelir \\
& Likit Varlıklar / Toplam Aktifler (Likit Varlık Oranı) \\
Likidite & Likit Varlıklar / Kısa Vadeli Yükümlülükler \\
& Yabancı Para Net Açık Pozisyon / Sermaye \\
\hline
\end{tabular}

Kaynak: IMF, 2006, Financial Soundness Indicators Compilation Guide, s.2

Ülkemizde de TCMB ve BDDK tarafindan finansal sağlamlık konusunda benzer çalışmalar yapılmış olup, ayrıntılarına aşağıda yer verilmiştir.

\section{TCMB Finansal Sağlamlık Endeksi}

Türkiye'de bankacılık sektörünün finansal sağlamlık ve kırılganlıklarının genel hatlarıyla tespit edilebilmesi ve tek bir göstergede özet bir şekilde 
izlenebilmesi amacıyla, seçilmiş bazı rasyolardan yararlanılarak TCMB tarafindan 2005 yılından itibaren finansal sağlamlık endeksi hesaplanmaya başlanmıştır (TCMB, 2005:1). Finansal Sağlamlık Endeksi (FSE), bankacılık sektörünün finansal yapısının sağlamlığının ne yönde hareket ettiğine ilişkin bir bileşik gösterge oluşturmak amacıyla hesaplanmaktadır (TCMB, 2010:80). Bu endeksin oluşturulmasında aktif kalitesi, likidite, kur riski, karlılık ve sermaye yeterliliği endekslerinin yer aldığ 5 alt gösterge kullanılmıştır. 2006 yılında TCMB finansal sağlamlık endeksinin oluşturulmasında yararlanılan göstergelere faiz riskini de dahil etmiştir (TCMB, 2006:112). Tablo 2'de endeksin hesaplanmasinda kullanılan finansal sağlamlık göstergeleri yer almaktadır.

Tablo 2: TCMB Tarafindan Kullanılan Finansal Sağlamlık Göstergeleri

\begin{tabular}{|c|c|c|c|}
\hline \multicolumn{2}{|c|}{ Finansal Sağlamlık Göstergeleri } & $\begin{array}{c}\text { Endekse Etkinin } \\
\text { Yönü }\end{array}$ & Ağırlık \\
\hline \multirow{3}{*}{$\begin{array}{l}\text { Aktif } \\
\text { Kalitesi }\end{array}$} & $\begin{array}{l}\text { Brüt Takipteki Alacaklar / Brüt } \\
\text { Kredi }\end{array}$ & Negatif & 0,33 \\
\hline & $\begin{array}{l}\text { Net Takipteki Alacaklar / Öz } \\
\text { kaynaklar }\end{array}$ & Negatif & 0,33 \\
\hline & Duran Aktifler / Toplam Aktifler ${ }^{1}$ & Negatif & 0,33 \\
\hline Likidite & Likit Aktif / Toplam Aktif ${ }^{2}$ & Pozitif & 1,00 \\
\hline \multirow[t]{2}{*}{ Kur Riski } & $\begin{array}{llcc}\text { Bilanço İçi } \quad \text { Yabancı } & \text { Para } \\
\text { Pozisyonu / Öz kaynaklar } & \\
\end{array}$ & Negatif & 0,50 \\
\hline & 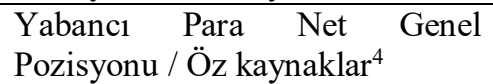 & Negatif & 0,50 \\
\hline \multirow[t]{2}{*}{ Faiz Riski } & $\begin{array}{l}\text { (1 Aya Kadar Faize Duyarlı TP } \\
\text { Cinsi Aktifler - } 1 \text { Aya Kadar } \\
\text { Faize Duyarlı TP Cinsi Pasifler) / } \\
\text { Öz kaynaklar } 5\end{array}$ & Negatif & 0,50 \\
\hline & $\begin{array}{l}\text { (1 Aya Kadar Faize Duyarlı YP } \\
\text { Cinsi Aktifler - 1 Aya Kadar } \\
\text { Faize Duyarlı YP Cinsi Pasifler) / } \\
\text { Öz kaynaklar }{ }^{5}\end{array}$ & Negatif & 0,50 \\
\hline \multirow[t]{2}{*}{ Kârlılık } & Net Kâr / Toplam Aktif & Pozitif & 0,50 \\
\hline & Net Kâr / Öz kaynaklar & Pozitif & 0,50 \\
\hline \multirow{2}{*}{$\begin{array}{l}\text { Sermaye } \\
\text { Yeterliliği }\end{array}$} & Serbest Sermaye / Toplam Aktif ${ }^{6}$ & Pozitif & 0,50 \\
\hline & Sermaye Yeterliliği Rasyosu & Pozitif & 0,50 \\
\hline
\end{tabular}


${ }^{2}$ Likit Aktifler; nakit değerler, Merkez Bankası, piyasalar, bankalar ve ters repo işlemlerinden alacaklar toplamından oluşmaktadır.

${ }^{3}$ Öz kaynaklar, yasal öz kaynak tanımı olup, bilançonun pasifinde yer alan öz kaynak tanımından farklıdır. Hesaplama mutlak değer olarak yapılmıştır.

${ }^{4}$ Bilanço içi yabancı para pozisyonu ile bilanço dışı kalemlerin toplanması ile yabancı para net genel pozisyonu elde edilmektedir. Hesaplama mutlak değer olarak yapilmıştır.

${ }^{5}$ Hesaplama mutlak değer olarak yapılmıştır.

${ }^{6}$ Serbest sermaye, öz kaynak tutarından duran aktiflerin çıkarılmasıyla hesaplanmaktadir.

Kaynak: TCMB (2010), Finansal İstikrar Raporu (Mayıs 2010)

Ayrıca Tablo 2'de, finansal sağlamlık endeksini oluşturan alt endeksler ile bu alt endeksleri oluşturan değişkenlerin (rasyoların) ağırlıkları ve endeksi ne yönde etkiledikleri de (pozitif ya da negatif) yer almaktadır. Pozitif değer değişkenler yükseldiğinde endeksin yükseleceğini; negatif değer ise değişkenler yükseldiğinde endeksin düşeceğini belirtmektedir. Diğer bir ifade ile endeksi pozitif veya negatif etkileyen rasyolar belirtilmiştir. Tablodaki her bir ağırlık, alt endeksleri oluştururken değişkenlere verilen ağırlıkları göstermektedir.

\section{BDDK- Bankacılık Sektörü Performans Endeksi}

Bankacılık Düzenleme ve Denetleme Kurumu (BDDK) tarafindan da bankacılık sektörü performansının takibi amacıyla Bankacılık Sektörü Performans Endeksi (BDDK-PE) oluşturulmuş ve bu endeks aylık olarak hesaplanmaya başlanmıştır (BDDK, 2004:35).

Bankacılık Sektörü Performans Endeksinde sektör performansının temel ölçütleri olarak belirlenen likidite, öz kaynak yeterliliği, kur (döviz) riski, karlılık ve aktif kalitesi bloklarına ilişkin olarak seçilen 10 adet gösterge kullanılmıştır. Seçilen göstergeler öncelikle ait oldukları blokta endekse dönüştürülmekte, sonraki aşamada ise bu endekslerin ağırlıklı ortalamaları alınarak bileşik endeks hesaplanmaktadır. BDDK-PE aylık frekansta hesaplanmakta olup TMSF bankaları hariç mevduat bankalarını kapsamaktadır. Endeks için baz dönem olarak 2003 Aralık ayı seçilmiştir (BDDK, 2004:35-36). 
BDDK'nın hazırladığı Eylül 2008 Finansal Piyasalar Raporu'nda finansal sağlamlık göstergelerine, bankaların borç ödeme kabiliyetlerinin izlenmesi amacıyla sıklıkla kullanılan borç ödenebilirlik rasyosu ve kaldıraç oranı da eklenmiştir. Borç ödeyebilirlik rasyosu toplam öz kaynakların toplam yabancı yükümlülüklere, kaldıraç oranı ise toplam öz kaynakların toplam aktiflere oranıdır (BDDK, 2008:21).

BDDK, IMF'nin finansal sağlamlık göstergelerinde mevduat kabul eden kuruluşlara ait 25 göstergeden temel set olarak adlandırılan ve tüm ülkelerce takip edilerek IMF'ye gönderilen temel sette yer alan 12 göstergeyi 2010 yılında Türk Bankacılık sektörü için hesaplamıştır. Sonraki dönemlerde BDDK bankacılık sektörünün finansal sağlamlık göstergelerini; bankacılık faaliyetleri, sermaye yeterliliği, aktif kalitesi, gelir-gider ve kârlılık olmak üzere dört temel başlık altında ele alarak raporlarına yansıtmıştır. Bu temel başlıklara ilişkin rasyolar Tablo 3 'te yer almaktadir.

Tablo 3: BDDK Tarafından Kullanılan Finansal Sağlamlık Göstergeleri

\begin{tabular}{|l|l|}
\hline \multicolumn{2}{|c|}{ Bankacılık Faaliyetlerine İlişkin Rasyolar } \\
\hline Etkinlik Rasyoları & Likidite Rasyoları \\
Krediler / Toplam Aktif & Yabancı Kaynaklar / Toplam Aktif \\
Yıllık Kredi Büyüme Oranı & Yabancı Kaynaklar / Öz kaynaklar \\
Menkul Kıymetler / Toplam Aktif & Öz kaynaklar / Toplam Aktif \\
Öz kaynaklar / Toplam Pasif & 1 aylık Likidite Yeterlik Oranı \\
Mevduat / Toplam Pasif & YP Krediler / Toplam Krediler \\
Krediler / Mevduat & YP Mevduat / Toplam Mevduat \\
Bilanço Dışı İşlemler / Toplam Aktifler & YP Aktifler / Toplam Aktifler \\
Türev İşlemler / Bilanço Dışı İşlemler & \\
\hline Sermaye Yeterliliğine İlişkin Rasyolar & Aktif Kalitesine İlişkin Rasyolar \\
Sermaye Yeterliliği Rasyosu & Takipteki Alacaklar (Brüt) / Krediler \\
Ana Sermaye / Risk Ağırlıklı Varlıklar & TGA Karşıllı̆̆ / Takipteki Alacaklar \\
(Net) & 1 Milyon TL'den Büyük Nakdi Kredi / \\
Ana Sermaye / Öz kaynaklar & Kredi \\
Serbest Öz kaynak / Toplam Öz & (Bireysel Kredi + Kredi Kartı) / Kredi \\
kaynaklar & Konut Kredileri / Nakdi Krediler \\
Aktifler / Öz kaynaklar & Teminatsız TGA / TGA \\
Takipteki Alacaklar (Net) / Öz kaynaklar & \\
Yab. Para Net Genel Poz. / Öz kaynaklar & \\
\hline
\end{tabular}




\section{Gelir - Gider ve Kârlıık Rasyolar}

Gelirler / Ortalama Aktifler

Kredilerden Alın. Faizler / Ortalama

Nakdi Krediler

Menkul Değ. Alınan Faizler / Ortalama

MDP

Mevduata Verilen Faizler / Ortalama

Mevduat

Net Faiz Marj1

Spread

Faiz Gelirleri / Gelirler

Faiz Giderleri / Giderler

Operasyon Giderleri / Giderler

Personel Giderleri / Giderler
Faiz Gelirleri / Faiz Giderler

Faiz D1şı Gelirler / Faiz Dışı Giderler

Giderler / Gelirler

Ücret, Kom. ve Bank. Hiz. Gel. / Gelirler

Vergi Sonrası Aktif Kârlılığı (ROA)

Vergi Sonrası Öz kaynak Kârlılığı

(ROE)

(Operasyon Giderleri: Personel Giderleri

+ Kıdem Tazminatı Karşılık Gideri +

Diğer İşletme Giderleri + Amortisman Giderleri)

Kaynak: BDDK (2012), Finansal Piyasalar Raporu (Eylül 2012)

\section{LITERATÜR TARAMASI}

Bankacılık sektörü, Avrupa Birliği ülkeleri, Entropi ve EDAS yöntemleri hakkında çeşitli veri ve oranlarla, çok kriterli karar verme yöntemleri kullanılmak suretiyle çeşitli çalışmalar yapılmıştır. Bu çalışmanın konusu içinde yer alan mevduat bankaları, IMF finansal sağlamlık göstergeleri, Avrupa Birliği ülkeleri, Entropi ve EDAS yöntemleri dikkate alınarak, literatürde bu başlıkların bir arada yer aldığı çalışma tespit edilememiştir. Ancak, bu başlıkların ayrı ayrı yer aldığı veya farklı konularda Entropi ve EDAS yönteminin kullanıldığı çalışmalar mevcut olup, ilgili olanlara aşağıda yer verilmiştir.

Işık, O. (2019) çalışmasında mevduat bankalarının 2008-2017 yı1ları arasındaki finansal performansını değerlendirmeyi amaçlamıştır. Sektörün performansı 8 değerlendirme kriteri (sermaye yeterlilik oranı, mevduatvarlık oranı, kredi-varlık oranı, takibe düşen krediler oranı, likit varlık oranı, aktif kârlılı̆̆1, faiz dışı gelirler oranı ve etkinsizlik oranı) kullanılarak, çok kriterli karar verme (ÇKKV) yöntemleriyle değerlendirilmiştir. Kriterlerin ağırlıklar Entropi yöntemine göre hesaplanmış ve y1llara ilişkin performans değerlendirmesi için ise ARAS yöntemi kullanılmıştır. Değerlendirme sonucunda performans değerlendirmesinde en yüksek ağırlığa sahip kriter faiz dışı gelirler oranı olmuştur. 
Kandemir ve Özarı (2019), çalışmalarında, Avrupa Birliği üyesi ülkeler ve Türkiye'nin yer aldığ1 toplam 29 ülkenin 2007-2017 y1lları temel makroekonomik göstergelerine dayalı ekonomik durumları Çok Kriterli Karar Verme Tekniklerinden TOPSIS ve EDAS yöntemleri ile değerlendirilerek, iki analizden elde edilen bulgular Kendall Tau korelasyon katsayısı ile karşılaştırılmıştır. Elde edilen bulgularda yöntemlerden elde edilen sonuçların uyumlu olduğu ancak sıralamada belirgin farklılıklar olduğu ifade edilmiştir.

Akbulut (2019) çalışmasında, Türk bankacılık sektöründe faaliyette bulunan İş Bankası'nın 2009-2018 yıllarına ait finansal performansı CRITIC ve EDAS yöntemleri ile değerlendirmiş, yıllara ilişkin başarı sıralamasının tespit edilmesinde EDAS yönteminden yararlanılmıştır.

Demireli, Ural ve Çalık (2018) çalışmalarında Entropi ve WASPAS yöntemleri kullanılarak Türkiye'de faaliyet gösteren 3 kamu sermayeli bankanın performanslarını, 2012-2016 dönemine ait temel finansal tablolarından sağlanan veriler ile incelemişlerdir.

Akçakanat, Eren vd. (2017), çalışmasında, aktif büyüklüklerine göre küçük, orta ve büyük ölçekli bankaların performansları çok kriterli karar verme yöntemlerinden ENTROPI ve WASPAS ile değerlendirilmiş, Forbes Dergisi Bankalar Raporu 2016 ve Türkiye Bankalar Birliği'nin 2016 yılı ilk 9 aylık verilerinden yararlanılarak; toplam aktifler, toplam krediler ve alacaklar, toplam mevduat, toplam öz kaynaklar, şube sayısı ve personel sayısı kriterleri belirlenmiş, kriter ağırlıkları ENTROPİ yöntemi ile hesaplanmış, daha sonra da WASPAS yöntemiyle bankaların performans sıralaması yapılmıştır.

Eyüboğlu (2016) çalışmasında, 2009-2013 dönemine ilişkin olarak 7 gelişmekte olan ülkenin (Arjantin, Brezilya, Endonezya, Polonya, Rusya, Güney Afrika ve Türkiye) bankacılık sektörünün performansının TOPSIS yöntemi kullanarak karşılaştırması ve sıralanması amaçlamış, performans ölçümünde ise IMF Finansal Sağlamlık göstergeleri içerisinde yer alan 10 finansal rasyodan yararlanılmıştır. 
Akkoç ve Vatansever (2013) çalışmalarında, Türkiye'de faaliyette bulunan 12 ticari bankanın verilerini kullanarak, sermaye oranları, aktif kalitesi, likidite, kârlılık, gelir harcama yapısı, faaliyet oranları, şube oranları başlıklarında sınıflandırılan 17 kriterden yararlanarak, Bulanık AHP ve Bulanık TOPSIS yöntemlerini ayrı ayrı kullanmak suretiyle bankacılık sektörünün finansal performans ölçülmüştür. Çalışmanın sonucunda, bankaların performans sıralamasının her iki yöntem için de benzer olduğu gözlemlenmiştir.

\section{ARAŞTIRMANIN AMACI}

Çalışmada, IMF tarafindan oluşturulan ve mevduat bankaları için temel set olarak kabul edilen 12 finansal sağlamlık göstergesi dikkate alınmış, Türkiye dahil 2004 yılı ve sonrası Avrupa Birliği’ne üye olan, mevcut aday ve potansiyel aday toplam 19 ülke verileri dikkate alınarak çalışma yapılmıştır. Türkiye'nin aday olması, üyeliğe kabul sürecinin uzatılması nedeniyle adaylık sürecimiz içinde aday olan ve bizden sonra aday olup AB'ye kabul edilen ülkelerin bankacılık sektörlerinin karşılaştırılması amaçlanmıştır. Çalışmada 12 temel kriterin ağırlıkları Entropi yöntemi ile tespit edilmiş, daha sonra EDAS yöntemi ile ülkelerin IMF tarafindan saplanan 2018 yılı verileri kullanılmış ve performans sıralaması yapılmıştır. Ülkeler ve AB'ye katılma tarihleri ve mevcut bilgileri şöyledir;

Tablo 4: 2004 Yılı ve Sonrasında AB Üyesi ve Aday Ülkeler

\begin{tabular}{|c|c|c|c|c|c|}
\hline & Ülkeler & AB Katılma Tarihi & & Ülkeler & AB Katılma Tarihi \\
\hline 1 & Arnavutluk & $*$ & 11 & Litvanya & 2004 \\
\hline 2 & Bosna Hersek & $* *$ & 12 & Malta & 2004 \\
\hline 3 & Bulgaristan & 2007 & 13 & Karadağ & $*$ \\
\hline 4 & Hırvatistan & 2013 & 14 & Polonya & 2004 \\
\hline 5 & Çek Cumhuriyeti & 2004 & 15 & Romanya & 2007 \\
\hline 6 & Kıbris & 2004 & 16 & Surbistan & $*$ \\
\hline 7 & Estonya & 2004 & 17 & Slovakya & 2004 \\
\hline 8 & Macaristan & 2004 & 18 & Slovenya & 2004 \\
\hline 9 & Kosova & $* *$ & 19 & Türkiye & $*$ \\
\hline 10 & Letonya & 2004 & & & \\
\hline
\end{tabular}




\section{ANALIZ}

IMF tarafından oluşturulan ve mevduat bankaları için temel set olarak kabul edilen 12 finansal gösterge dikkate alınmış ve IMF web sitesinden toplu ve ülke bazında yayımlanan 2018 yılı verileri elde edinilmiştir. Kriter ağırlıkları Entropi yöntemi ile tespit edilmiş, daha sonra bu kriterler EDAS yöntemi ile ülkelerin performans sıralaması yapılmıştır. Finansal sağlamlık göstergeleri, kodları, min. ve mak. bilgileri aşağıda yer alan Tablo 5'te gösterilmiştir.

Tablo 5: Değerlendirme Kriterleri, Kodları ve Ağırlıkları

\begin{tabular}{|c|c|c|c|c|}
\hline & Kodlar & Kriterler & & $\begin{array}{c}\text { Kriter } \\
\text { A ğırlığı* }\end{array}$ \\
\hline \multirow{3}{*}{$\begin{array}{l}\text { Sermaye } \\
\text { Yeterliliği }\end{array}$} & $\mathbf{A}_{1}$ & $\begin{array}{l}\text { Yasal Öz kaynak / Risk Ağırlıklı } \\
\text { Varlıklar }\end{array}$ & MAK & 0,0049 \\
\hline & $\mathbf{A}_{2}$ & $\begin{array}{l}\text { Birinci Kuşak Sermaye / Risk } \\
\text { Ağırlıklı Varlıklar }\end{array}$ & MAK & $\mathbf{0 , 0 0 6 7}$ \\
\hline & $\mathbf{A}_{3}$ & $\begin{array}{l}\text { Net Takipteki Alacaklar / } \\
\text { Sermaye }\end{array}$ & MIN & 0,2516 \\
\hline \multirow{2}{*}{ Varlık Kalitesi } & $\mathbf{A}_{4}$ & $\begin{array}{l}\text { Takipteki Alacaklar / Toplam } \\
\text { Krediler }\end{array}$ & MiN & 0,1206 \\
\hline & $\mathbf{A}_{5}$ & $\begin{array}{lll}\begin{array}{l}\text { Kredilerin } \\
\text { (Yerleşik) }\end{array} & \text { Sektörel } & \text { Dağılımı } \\
\end{array}$ & MAK & 0,0043 \\
\hline \multirow{4}{*}{$\begin{array}{l}\text { Gelir ve } \\
\text { Kârlılık }\end{array}$} & $\mathbf{A}_{6}$ & Net Kâr / Toplam Aktifler & MAK & $\mathbf{0 , 0 2 8 7}$ \\
\hline & $\mathbf{A}_{7}$ & Net Kâr / Öz kaynaklar & MAK & $\mathbf{0 , 0 2 2 7}$ \\
\hline & $\mathbf{A s}_{8}$ & Faiz Marjı / Toplam Gelir & MAK & 0,0099 \\
\hline & A9 & $\begin{array}{l}\text { Faiz Dişı Giderler / Toplam } \\
\text { Gelir }\end{array}$ & MIN & 0,0094 \\
\hline \multirow{2}{*}{ Likidite } & $\mathbf{A}_{10}$ & $\begin{array}{l}\text { Likit Varlıklar / Toplam Aktifler } \\
\text { (Likit Varlık Oranı) }\end{array}$ & MAK & $\mathbf{0 , 0 2 9 5}$ \\
\hline & $\mathbf{A}_{11}$ & $\begin{array}{l}\text { Likit Varlıklar / Kısa Vadeli } \\
\text { Yükümlülükler }\end{array}$ & MAK & $\mathbf{0 , 0 7 3 6}$ \\
\hline $\begin{array}{l}\text { Piyasa Riskine } \\
\text { Duyarlılık }\end{array}$ & $\mathbf{A}_{12}$ & $\begin{array}{l}\text { Yabancı Para Net Açık Pozisyon } \\
\text { / Sermaye }\end{array}$ & MİN & 0,4379 \\
\hline
\end{tabular}

*Kriter ağırlıkları Entropi Yöntemi sonucu bulunan ağırlıklardır. 


\section{VERI VE METODOLOJI}

Karar verme, uygulanabilir alternatifler arasında en iyi seçeneği bulma sürecidir. Çok Kriterli Karar Verme (ÇKKV), çoklu çatışma kriterlerinin değerlendirilmesine dayalı karşılaştırma için etkili bir çerçeve sunmakta (Vahdani vd., 2010:1231), birbiriyle çelişen çoklu amaçları olan problem çözme yöntemi olup (Zionts, 1979:94), birçok seçenek arasından birbirini etkileyebilen kriterler dikkate alınarak en uygun seçenek ya da seçeneklerin belirlenmesi olarak ifade edilmektedir. Çok kriterli seçme, sıralama ve değerlendirme yöntemleri, basit analitik tekniklerden, çok kriterli karmaşık yöntemleri kapsayacak şekilde literatürde yer almıştır (Özbek ve Engür, 2019:3).

Bir karar vericinin sorunu, en iyisini bulabilmek, en iyiden en kötüye doğru sıralayabilmek, onları önceden tanımlanmış homojen gruplara ayırabilmek ya da her bir alternatifin tüm kriterleri aynı anda nasıl karşıladığını açıklayabilmek için sınırlı bir alternatifler dizisini değerlendirmeyi içermektedir (Zavadskas ve Turskis, 2010:160). ÇKKV Yöntemleri birden çok etkenin bulunduğu, alternatifler arasında karar verme süreci ile ilgilenirler. Farklı özelliklere sahip olan alternatifleri, belirlenen birçok kritere göre değerlendiren karar vericiler, alternatifin seçimi ve sıralanmasında bu yöntemlerden yararlanmaktadır. Yapılan değerlendirme sonucunda alternatiflerin kriterlere ilişkin performans değerleri kriter ağırlıkları ile çarpılarak alternatiflere ilişkin skorlar elde edilmektedir (Özden, 2009: 63-64). Bazen amaçlar birbiriyle çatışabilmektedir. Bir başka ifadeyle bir amaç için optimal çözüm değeri diğerleri için optimal olmayabilmektedir (Akkoç ve Vatansever, 2013:57).

\section{YÖNTEM}

Alternatiflerin değerlendirilmesinde, her bir kriterin ağırlığı uzman ve karar vericiler tarafindan sübjektif olarak belirlenebilmektedir (Özden, 2009, 63-64). Herhangi bir karar vericinin kişisel görüşlerine ihtiyaç duyulmaksızın, objektif olarak kriter ağırlıklarının belirlendiği ve hesaplanması kolay olduğundan (Apan vd., 2016; Erol vd., 2011) bu çalışmada kriter ağırlıkları Entropi yöntemi ile belirlenmiştir. Daha sonra karar matrisi ve belirlenen ağırlıklar, EDAS Yöntemi kullanılarak ülkelerin performans sıralamaları tespit edilmiştir. 


\section{Entropi Yöntemi}

Her kriterin farklı bir anlamı olduğu için hepsinin eşit ağırlığa sahip olduğu varsayılamaz ve sonuç olarak her kriter için uygun ağırlığı bulmak ÇKKV'deki en önemli hususlardan biridir. Ağırlıkları bulmak için farklı yöntemler vardır ve bunların çoğu iki gruba ayrılabilir: öznel ve nesnel ağırlıklar. Öznel ağırlıklar, yalnızca tercih karar vericilere göre belirlenir. AHP yöntemi, ağırlıklandırılmış en küçük kareler yöntemi ve Delphi yöntemi bu gruba girmektedir. Nesnel yöntemler, karar vericinin tercihlerini dikkate almadan matematiksel modelleri çözerek ağırlıkları belirler; örneğin entropi yöntemi, çok amaçlı programlama (multiple objective programming) yöntemi olup, gerçek problemlerde karar vericinin uzmanlığı ve yargısı yani öznel ağırlık tercih edilebilir, ancak güvenilir öznel ağırlıkların elde edilmesi zor olduğunda, objektif ağırlıkların kullanılması yararlı olacaktır.

Araştırmacılar tarafından önerilen nesnel ağırlıklandırma ölçütlerinden biri Shannon entropi konseptidir. Entropi kavramı çeşitli bilimsel alanlarda kullanılmıştır. Shannon'un entropi kavramının bilgi teorisinde önemli bir rolü vardır ve genel bir belirsizlik ölçüsünü belirtmek için kullanılmaktadır (Lotfi ve Fallahnejad,2010: 54).

Karar matrisinde negatif değerlerin bulunması hesaplamayı zorlaştırmaktadır. Z-Skor standardizasyon yöntemi, maksimum ve maksimumun net olmadığ 1 veya değerin belirli bir aralığı aştığ 1 ayrı veriler için uygulanır. Bu dönüşümün kullanıldığı geliştirilmiş entropi (improved entropy) yönteminden yararlanmak mümkündür (Xianqi, Wang, Li ve Xu, 2014;3). Z-Skor standardizasyonunda formül şu şekilde ifade edilebilir;

$$
\mathrm{X} i j=\frac{(\mathrm{X} i j-\ddot{\mathrm{X}} i)}{\mathrm{S} i}
$$

Negatif değerlerin yanlış hesaplamalarından kaçınmak için, standart karar matrisinde her bir Xji kriterin standart sapması ve ortalaması bulunarak, yukarıdaki eşitlikle koordinat dönüşüm yöntemi ile değerlerin $(\mathrm{X} i j)$ pozitif olması sağlanır. 
Entropi yöntemi ile, herhangi bir karar vericinin kişisel görüşlerine ihtiyaç duyulmaksızın, objektif olarak kriter ağırlıkları belirlendiği ve hesaplanması kolay olduğundan oldukça kullanışlıdır. Entropinin güçlü yönü karar vericilerin değerlendirmelerine ve kişisel görüşlerine ihtiyaç duymadan alternatiflere ilişkin veriler kullanılarak objektif sonuçlar sağlaması ve hesaplanmasının kolay olmasından dolayı oldukça kullanışlıdır. Bu yöntemde değeri yüksek olan veri grubunda belirsizlik daha fazla olmaktadır (Ayçin, 2019:122).

Çalışmada, kriter ağırlıklarını belirlemede kullanılan Entropi yönteminin işlem adımları ve yer alan değişkenlere ilişkin tanımlara aşağıda verilmiştir (Ayçin, 2019:122-123; Kenger ve Organ, 2017: 154-156; Tunca vd. 2016: 7-10; Bakır ve Atalık,2018 :621-623)

$i=$ karar alternatifi $(i=1,2, \ldots, \mathrm{m})$

$j=$ değerlendirme kriteri $(\mathrm{j}=1,2, \ldots, \mathrm{n})$

$r_{i j}=$ normalize edilmiş değerler

$x_{i j}=j$. değerlendirme kriterine göre $i$. alternatifinin aldığ 1 değer

$k=$ entropi katsayıs

$r_{i j}=$ normalize edilmiş değerler

$e_{j} \quad=$ entropi değeri

$\mathrm{w}_{j}=$ ağırlık değeri, $(\mathrm{j}=1,2, \ldots, \mathrm{n})$

$d_{j} \quad=$ farklilaşma derecesi

Adım 1: Karar Matrisinin Oluşturulması

Entropi yönteminde de diğer çok kriterleri karar verme problemlerinde olduğu gibi öncelikle $\mathrm{X}_{i j}$ değerlerinden oluşan ve $\mathrm{X}$ ile simgelenen karar matrisi Eşitlik (1)'de gösterilen şekilde oluşturulur.

$$
x=\left[\begin{array}{ccc}
x_{11} & x_{12} & \ldots x_{1 n} \\
x_{21} & x_{22} & \ldots x_{2 n} \\
& & \vdots \\
x_{m_{1}} & x m_{2} & \ldots x_{m n}
\end{array}\right]
$$

Eşitlik (1) ile oluşturulan ve 19 ülkeye (alternatif) ait 12 kriterin yer aldığ 1 karar matrisi Tablo 6'da yer almaktadır. 
Türkiye ve Seçilmiş Ülkelerde Mevduat Kabul Eden Kuruluşların Finansal Sağlamlık

Göstergelerinin Entropi ve Edas Yöntemi ile Değerlendirilmesi

Tablo 6: Karar Matrisi

\begin{tabular}{|l|c|c|c|c|c|c|c|c|c|c|c|c|}
\hline $\begin{array}{l}\mathbf{2 0 1 8} \\
\text { Verileri }\end{array}$ & $\mathbf{A}_{\mathbf{1}}$ & $\mathbf{A}_{\mathbf{2}}$ & $\mathbf{A}_{\mathbf{3}}$ & $\mathbf{A}_{\mathbf{4}}$ & $\mathbf{A}_{\mathbf{5}}$ & $\mathbf{A}_{\mathbf{6}}$ & $\mathbf{A}_{\mathbf{7}}$ & $\mathbf{A}_{\mathbf{8}}$ & $\mathbf{A}_{\mathbf{9}}$ & $\mathbf{A}_{\mathbf{1 0}}$ & $\mathbf{A}_{\mathbf{1 1}}$ & $\mathbf{A}_{\mathbf{1 2}}$ \\
\hline Arnavutluk & 18,24 & 16,99 & 15,01 & 11,08 & 86,00 & 1,20 & 12,96 & 100,82 & 77,65 & 14,77 & 19,93 & 7,78 \\
\hline $\begin{array}{l}\text { Bosna } \\
\text { Hersek }\end{array}$ & 17,53 & 16,49 & 12,15 & 8,77 & 98,41 & 1,31 & 9,65 & 58,83 & 74,00 & 29,74 & 44,66 & 2,24 \\
\hline Bulgaristan & 20,38 & 19,41 & 28,22 & 7,80 & 94,60 & 1,59 & 11,83 & 65,07 & 44,84 & 28,89 & 35,78 & 0,22 \\
\hline Hırvatistan & 22,90 & 21,83 & 12,90 & 9,71 & 97,01 & 1,40 & 9,62 & 56,62 & 54,30 & 34,36 & 47,07 & 5,07 \\
\hline Kıbris & 17,32 & 16,38 & 100,71 & 19,52 & 78,09 & 0,55 & 6,40 & 51,73 & 51,91 & 37,00 & 47,10 & 0,10 \\
\hline $\begin{array}{l}\text { Cek } \\
\text { Cumhuriyeti }\end{array}$ & 18,29 & 17,78 & 11,41 & 3,14 & 90,47 & 1,10 & 17,34 & 64,85 & 47,10 & 15,20 & 29,97 & 1,04 \\
\hline Estonya & 28,51 & 28,07 & 1,90 & 0,45 & 97,30 & 1,76 & 13,31 & 43,57 & 47,51 & 22,51 & 33,32 & $\mathbf{2 3 , 6 1}$ \\
\hline Macaristan & 18,46 & 16,69 & 3,19 & 2,47 & 91,83 & 1,95 & 19,38 & 47,71 & 70,06 & 26,99 & 41,64 & $\mathbf{1 , 0 5}$ \\
\hline Kosova & 16,96 & 15,45 & 1,45 & 2,52 & 94,10 & 2,31 & 18,30 & 78,41 & 48,16 & 28,98 & 40,00 & 3,84 \\
\hline Letonya & 22,31 & 20,30 & 21,73 & 5,29 & 84,49 & 1,18 & 9,54 & 46,37 & 67,90 & 29,98 & 37,15 & 0,91 \\
\hline Litvanya & 18,58 & 18,45 & 17,95 & 2,27 & 100,00 & 1,51 & 16,78 & 54,68 & 54,00 & 25,52 & 31,32 & 0,02 \\
\hline Malta & 18,13 & 16,00 & 16,78 & 3,35 & 79,38 & 0,71 & 8,39 & 67,59 & 59,17 & 28,31 & 37,48 & $\mathbf{0 , 0 1}$ \\
\hline Karadağ & 15,63 & 14,36 & 8,63 & 7,43 & 95,17 & 1,01 & 8,49 & 56,07 & 76,35 & 22,57 & 35,43 & 0,02 \\
\hline Polonya & 18,34 & 16,31 & 9,42 & 3,85 & 96,07 & 0,71 & 7,55 & 62,84 & 60,19 & 14,37 & 25,16 & 0,13 \\
\hline Romanya & 20,71 & 18,64 & 12,30 & 4,96 & 91,25 & 1,55 & 14,59 & 65,42 & 53,17 & 52,62 & 170,65 & 0,66 \\
\hline Sirbistan & 22,30 & 21,10 & 9,70 & 5,70 & 49,10 & 2,20 & 11,30 & 52,70 & 58,40 & 50,50 & 35,70 & 4,30 \\
\hline Slovakya & 18,43 & 16,73 & 6,93 & 3,08 & 93,43 & 1,06 & 10,11 & 72,79 & 59,62 & 26,99 & 35,38 & 0,77 \\
\hline Slovenya & 17,95 & 17,63 & 2,71 & 1,84 & 88,03 & 1,44 & 11,32 & 53,21 & 83,69 & 32,28 & 50,99 & 8,40 \\
\hline Türkiye & 17,30 & 13,99 & 5,93 & 3,69 & 97,49 & 1,78 & 16,95 & 67,42 & 41,95 & 47,05 & 64,01 & 1,52 \\
\hline
\end{tabular}

Not: Estonya, Macaristan ve Malta'nın 12.kriter değerleri negatiftir. Mutlak değerleri alınmıştır. Çünkü, bu oranın sıfıra yakın olması tercih edilir. Dolayısıyla açık pozisyon döviz varlıkları ile döviz yükümlülükleri arasındaki fark olup, negatif ve pozitif her iki durum açık pozisyonu ifade etmektedir. Örneğin -1 ile +1 aynı oranda açıkpozisyonu ifade eder. Pozitifte döviz varlıkları, negatifte döviz yükümlükleri fazladır.

\section{Adım 2: Karar Matrisinin Normalizasyonu}

Karar problemlerinde yer alan farklı birimlere sahip kriterlere ilişkin değerler, normalizasyon işlemiyle $(0,1)$ aralığında değer alacak şekilde Eşitlik (2)'den yararlanarak standart hale getirilir. Bu aşamada, her bir kriterin $\left(A_{1}, A_{2}, \ldots, A_{12}\right)$ toplamı alınır, her bir kriter (Arnavutluk $A_{1}$ ) kriter toplamına ( $\mathrm{A}_{1}$ toplamı) bölünür, tüm kriterler için bu uygulandıktan sonra normalize edilmiş karar matrisi elde edilir.

$$
r_{i j}=\frac{X_{i j}}{\sum_{1}^{j} x_{i j}}
$$


Eşitlik (2)'den yararlanarak elde edilen normalize edilmiş karar matrisi Tablo 7'de yer almıştır.

Tablo 7: Karar Matrisinin Normalizasyonu

\begin{tabular}{|l|c|c|c|c|c|c|c|c|c|c|c|c|}
\hline $\begin{array}{l}\mathbf{2 0 1 8} \\
\text { Verileri }\end{array}$ & $\mathbf{A}_{\mathbf{1}}$ & $\mathbf{A}_{\mathbf{2}}$ & $\mathbf{A}_{\mathbf{3}}$ & $\mathbf{A}_{\mathbf{4}}$ & $\mathbf{A}_{\mathbf{5}}$ & $\mathbf{A}_{\mathbf{6}}$ & $\mathbf{A}_{\mathbf{7}}$ & $\mathbf{A}_{\mathbf{8}}$ & $\mathbf{A}_{\mathbf{9}}$ & $\mathbf{A}_{\mathbf{1 0}}$ & $\mathbf{A}_{\mathbf{1 1}}$ & $\mathbf{A}_{\mathbf{1 2}}$ \\
\hline Arnavutluk & 0,050 & 0,050 & 0,050 & 0,104 & 0,051 & 0,045 & 0,055 & 0,086 & 0,069 & 0,026 & 0,023 & 0,126 \\
\hline $\begin{array}{l}\text { Bosna } \\
\text { Hersek }\end{array}$ & 0,048 & 0,048 & 0,041 & 0,082 & 0,058 & 0,050 & 0,041 & 0,050 & 0,065 & 0,052 & 0,052 & 0,036 \\
\hline Bulgaristan & 0,055 & 0,057 & 0,094 & 0,073 & 0,056 & 0,060 & 0,051 & 0,056 & 0,040 & 0,051 & 0,041 & 0,004 \\
\hline Hırvatistan & 0,062 & 0,064 & 0,043 & 0,091 & 0,057 & 0,053 & 0,041 & 0,049 & 0,048 & 0,060 & 0,055 & 0,082 \\
\hline KIbris & 0,047 & 0,048 & 0,337 & 0,183 & 0,046 & 0,021 & 0,027 & 0,044 & 0,046 & 0,065 & 0,055 & 0,002 \\
\hline $\begin{array}{l}\text { Çek } \\
\text { Cumhuriyeti }\end{array}$ & 0,050 & 0,052 & 0,038 & 0,029 & 0,053 & 0,042 & 0,074 & 0,056 & 0,042 & 0,027 & 0,035 & 0,017 \\
\hline Estonya & 0,077 & 0,082 & 0,006 & 0,004 & 0,057 & 0,067 & 0,057 & 0,037 & 0,042 & 0,040 & 0,039 & 0,383 \\
\hline Macaristan & 0,050 & 0,049 & 0,011 & 0,023 & 0,054 & 0,074 & 0,083 & 0,041 & 0,062 & 0,047 & 0,048 & 0,017 \\
\hline Kosova & 0,046 & 0,045 & 0,005 & 0,024 & 0,055 & 0,088 & 0,078 & 0,067 & 0,043 & 0,051 & 0,046 & 0,062 \\
\hline Letonya & 0,061 & 0,059 & 0,073 & 0,049 & 0,050 & 0,045 & 0,041 & 0,040 & 0,060 & 0,053 & 0,043 & 0,015 \\
\hline Litvanya & 0,050 & 0,054 & 0,060 & 0,021 & 0,059 & 0,057 & 0,072 & 0,047 & 0,048 & 0,045 & 0,036 & 0,000 \\
\hline Malta & 0,049 & 0,047 & 0,056 & 0,031 & 0,047 & 0,027 & 0,036 & 0,058 & 0,052 & 0,050 & 0,043 & 0,000 \\
\hline Karadag & 0,042 & 0,042 & 0,029 & 0,069 & 0,056 & 0,038 & 0,036 & 0,048 & 0,068 & 0,040 & 0,041 & 0,000 \\
\hline Polonya & 0,050 & 0,048 & 0,032 & 0,036 & 0,056 & 0,027 & 0,032 & 0,054 & 0,053 & 0,025 & 0,029 & 0,002 \\
\hline Romanya & 0,056 & 0,054 & 0,041 & 0,046 & 0,054 & 0,059 & 0,062 & 0,056 & 0,047 & 0,093 & 0,198 & 0,011 \\
\hline Surbistan & 0,061 & 0,062 & 0,032 & 0,053 & 0,029 & 0,084 & 0,048 & 0,045 & 0,052 & 0,089 & 0,041 & 0,070 \\
\hline Slovakya & 0,050 & 0,049 & 0,023 & 0,029 & 0,055 & 0,040 & 0,043 & 0,062 & 0,053 & 0,047 & 0,041 & 0,012 \\
\hline Slovenya & 0,049 & 0,051 & 0,009 & 0,017 & 0,052 & 0,055 & 0,048 & 0,046 & 0,074 & 0,057 & 0,059 & 0,136 \\
\hline Türkiye & 0,047 & 0,041 & 0,020 & 0,034 & 0,057 & 0,068 & 0,073 & 0,058 & 0,037 & 0,083 & 0,074 & 0,025 \\
\hline
\end{tabular}

Adım 3: Kriterlere İlişkin Entropi Değerlerinin Bulunması

$\mathrm{Bu}$ adımda, her bir değerlendirme kriterinin entropi değerleri $\left(e_{\mathrm{j}}\right)$ Eşitlik (3) yardımiyla bulunur:

$$
e_{j}=-k \sum_{j=1}^{m} r_{i j} \ln \left(r_{i j}\right) \quad(i=1,2, \ldots, m \text { ve } j=1,2, \ldots, n)
$$

$\mathrm{k}=(\ln (\mathrm{m}))^{1}$ olarak tanımlanan sabit bir katsayıdır ve $0 \leq \mathrm{e}_{j} \leq 1$ olacak şekilde değer alır. $\mathrm{e}_{j}$ değeri, $j$. kriterin belirsizlik ölçüsü ya da diğer bir ifadeyle entropi değeri olarak tanımlanır. Eşitlik (3)'den yararlanarak bulunan entropi değerleri Tablo 8'de yer almıştır. 
Türkiye ve Seçilmiş Ülkelerde Mevduat Kabul Eden Kuruluşların Finansal Sağlamlık

Göstergelerinin Entropi ve Edas Yöntemi ile Değerlendirilmesi

Tablo 8: Kriterlere İlişkin Entropi Değerlerinin $\left(e_{\mathrm{j}}\right)$ Bulunması

\begin{tabular}{|c|c|c|c|c|c|c|c|c|c|c|c|c|}
\hline $\begin{array}{l}2018 \\
\text { Verileri }\end{array}$ & $\mathbf{A}_{1}$ & $\mathbf{A}_{2}$ & $\mathbf{A}_{3}$ & $\mathbf{A}_{4}$ & $\mathbf{A}_{5}$ & $\mathbf{A}_{6}$ & $\mathbf{A}_{7}$ & $\mathbf{A}_{8}$ & A9 & $\mathbf{A}_{10}$ & $\mathbf{A}_{11}$ & $\mathbf{A}_{12}$ \\
\hline Arnavutluk & $-0,149$ & $-0,149$ & $-0,150$ & $-0,235$ & $-0,151$ & $-0,141$ & $-0,160$ & $-0,212$ & $-0,184$ & $-0,095$ & $-0,087$ & $-0,261$ \\
\hline $\begin{array}{l}\text { Bosna } \\
\text { Hersek } \\
\end{array}$ & $-0,145$ & $-0,146$ & $-0,130$ & $-0,205$ & $-0,165$ & $-0,149$ & $-0,132$ & $-0,151$ & $-0,179$ & $-0,154$ & $-0,153$ & $-0,120$ \\
\hline Bulgaristan & $-0,160$ & $-0,163$ & $-0,223$ & $-0,191$ & $-0,161$ & $-0,170$ & $-0,151$ & $-0,161$ & $-0,128$ & $-0,151$ & $-0,132$ & $-0,020$ \\
\hline Hurvatistan & $-0,173$ & $-0,175$ & $-0,136$ & $-0,218$ & $-0,163$ & $-0,156$ & $-0,131$ & $-0,147$ & $-0,146$ & $-0,170$ & $-0,159$ & $-0,205$ \\
\hline Kıbris & $-0,144$ & $-0,145$ & $-0,367$ & $-0,310$ & $-0,141$ & $-0,081$ & $-0,098$ & $-0,138$ & $-0,142$ & $-0,178$ & $-0,159$ & $-0,010$ \\
\hline $\begin{array}{l}\text { Çek } \\
\text { Cumhuriyeti } \\
\end{array}$ & $-0,149$ & $-0,154$ & $-0,125$ & $-0,104$ & $-0,156$ & $-0,133$ & $-0,193$ & $-0,161$ & $-0,132$ & $-0,097$ & $-0,117$ & $-0,069$ \\
\hline Estonya & $-0,198$ & $-0,205$ & $-0,032$ & $-0,023$ & $-0,164$ & $-0,181$ & $-0,163$ & $-0,123$ & $-0,133$ & $-0,128$ & $-0,126$ & $-0,368$ \\
\hline Macaristan & $-0,150$ & $-0,147$ & $-0,048$ & $-0,087$ & $-0,158$ & $-0,193$ & $-0,206$ & $-0,131$ & $-0,172$ & $-0,145$ & $-0,146$ & $-0,069$ \\
\hline Kosova & $-0,142$ & $-0,140$ & $-0,026$ & $-0,088$ & $-0,160$ & $-0,214$ & $-0,199$ & $-0,181$ & $-0,134$ & $-0,152$ & $-0,142$ & $-0,173$ \\
\hline Letonya & $-0,170$ & $-0,167$ & $-0,191$ & $-0,149$ & $-0,149$ & $-0,139$ & $-0,131$ & $-0,128$ & $-0,169$ & $-0,155$ & $-0,135$ & $-0,062$ \\
\hline Litvanya & $-0,151$ & $-0,157$ & $-0,169$ & $-0,082$ & $-0,167$ & $-0,164$ & $-0,189$ & $-0,143$ & $-0,145$ & $-0,139$ & $-0,120$ & $-0,003$ \\
\hline Malta & $-0,148$ & $-0,143$ & $-0,162$ & $-0,109$ & $-0,143$ & $-0,097$ & $-0,119$ & $-0,165$ & $-0,154$ & $-0,149$ & $-0,136$ & $-0,001$ \\
\hline Karadağ & $-0,134$ & $-0,133$ & $-0,102$ & $-0,185$ & $-0,161$ & $-0,125$ & $-0,120$ & $-0,146$ & $-0,182$ & $-0,128$ & $-0,131$ & $-0,003$ \\
\hline Polonya & $-0,149$ & $-0,145$ & $-0,109$ & $-0,120$ & $-0,162$ & $-0,098$ & $-0,111$ & $-0,157$ & $-0,156$ & $-0,093$ & $-0,103$ & $-0,013$ \\
\hline Romanya & $-0,162$ & $-0,158$ & $-0,131$ & $-0,142$ & $-0,157$ & $-0,167$ & $-0,173$ & $-0,162$ & $-0,144$ & $-0,220$ & $-0,321$ & $-0,049$ \\
\hline Sirbistan & $-0,170$ & $-0,172$ & $-0,111$ & $-0,156$ & $-0,102$ & $-0,207$ & $-0,146$ & $-0,140$ & $-0,153$ & $-0,215$ & $-0,132$ & $-0,186$ \\
\hline Slovakya & $-0,150$ & $-0,147$ & $-0,087$ & $-0,102$ & $-0,159$ & $-0,130$ & $-0,136$ & $-0,173$ & $-0,155$ & $-0,145$ & $-0,131$ & $-0,055$ \\
\hline Slovenya & $-0,147$ & $-0,153$ & $-0,043$ & $-0,070$ & $-0,153$ & $-0,159$ & $-0,147$ & $-0,141$ & $-0,193$ & $-0,163$ & $-0,167$ & $-0,271$ \\
\hline Türkiye & $-0,144$ & $-0,131$ & $-0,078$ & $-0,116$ & $-0,164$ & $-0,182$ & $-0,190$ & $-0,165$ & $-0,122$ & $-0,206$ & $-0,193$ & $-0,091$ \\
\hline TOPLAM & $-2,934$ & $-2,930$ & $-2,419$ & $-2,692$ & $-2,935$ & $-2,884$ & $-2,897$ & $-2,924$ & $-2,925$ & $-2,883$ & $-2,791$ & $-2,029$ \\
\hline In (m) & 0,3396 & & & & & & & & & & & \\
\hline ej & 0,9965 & $\mathbf{0 , 9 9 5 3}$ & $\mathbf{0 , 8 2 1 4}$ & 0,9144 & 0,9969 & $\mathbf{0 , 9 7 9 6}$ & 0,9839 & 0,9930 & 0,9933 & 0,9790 & $\mathbf{0 , 9 4 7 7}$ & 0,6892 \\
\hline
\end{tabular}


Adım 4: Farklılaşma Derecelerinin ( $d j$ ) Hesaplanması

Adım 3 'te hesaplanan entropi değerleri kullanılarak, farklılaşma dereceleri olan $\mathrm{d}_{j}$ değerleri her bir kriter için Eşitlik (4) yardımı ile aşağıda gösterilen şekilde hesaplanır.

$$
d_{\mathrm{j}}=1-e_{\mathrm{j}} \quad i=1,2, \ldots, m \quad \text { ve } j=1,2, \ldots, n
$$

Eşitlik (4) yardımıyla elde edilen ve Tablo 9'da gösterilen $d_{j}$ değerlerinin yüksek olması, kriterlere ilişkin alternatif skorları arasındaki uzaklığın veya farklılaşmanın fazla olduğunu göstermektedir.

Tablo 9: Farklılaşma Derecesinin ( $d j)$ Hesaplanması

\begin{tabular}{|c|c|c|c|c|c|c|cc|c|c|c|c|}
\hline & $\mathbf{A}_{\mathbf{1}}$ & $\mathbf{A}_{\mathbf{2}}$ & $\mathbf{A}_{\mathbf{3}}$ & $\mathbf{A}_{\mathbf{4}}$ & $\mathbf{A}_{\mathbf{5}}$ & $\mathbf{A}_{\mathbf{6}}$ & $\mathbf{A}_{\mathbf{7}}$ & $\mathbf{A}_{\mathbf{8}}$ & $\mathbf{A}_{\mathbf{9}}$ & $\mathbf{A}_{\mathbf{1 0}}$ & $\mathbf{A}_{\mathbf{1 1}}$ & $\mathbf{A}_{\mathbf{1 2}}$ \\
\hline TOPLAM & $-2,934$ & $-2,930$ & $-2,419$ & $-2,692$ & $-2,935$ & $-2,884$ & $-2,897$ & $-2,924$ & $-2,925$ & $-2,883$ & $-2,791$ & $-2,029$ \\
\hline $\mathbf{1 0} \mathbf{8}(\mathbf{m})$ & 0,3396 & \multicolumn{10}{|c|}{} \\
\hline $\mathbf{e} \boldsymbol{j}$ & 0,9965 & 0,9953 & 0,8214 & 0,9144 & 0,9969 & 0,9796 & 0,9839 & 0,9930 & 0,9933 & 0,9790 & 0,9477 & 0,6892 \\
\hline $\mathbf{d} \boldsymbol{j}$ & $\mathbf{0 , 0 0 3 5}$ & $\mathbf{0 , 0 0 4 7}$ & $\mathbf{0 , 1 7 8 6}$ & $\mathbf{0 , 0 8 5 6}$ & $\mathbf{0 , 0 0 3 1}$ & $\mathbf{0 , 0 2 0 4}$ & $\mathbf{0 , 0 1 6 1}$ & $\mathbf{0 , 0 0 7 0}$ & $\mathbf{0 , 0 0 6 7}$ & $\mathbf{0 , 0 2 1 0}$ & $\mathbf{0 , 0 5 2 3}$ & $\mathbf{0 , 3 1 0 8}$ \\
\hline
\end{tabular}

Adım 5: Entropi Kriter Ağırlıklarının Hesaplanması

Adım 5'te, Eşitlik (5)'ten yararlanarak, her bir kriterin farklılaşma derecesini, toplam farklılaşma derecesine oranlayarak kriterlerin ağırlık değerleri $(w j)$ elde edilir $\left(d_{j}=1-e_{j}\right)$.

$$
w_{j}=\frac{1-e_{j}}{\sum_{i=1}^{n}\left(1-e_{j}\right)}
$$

Yukarıdaki formülde yer alan $e_{\mathrm{j}}$ değeri, kriterlere ait Entropi değerlerini gösterirken, $w_{j}$ değeri kriterlerin önem düzeylerinin göstergesi olan ağırlık değerlerini ifade etmekte ve değerlerin toplamı daima 1'e eşittir (Çatı vd., 2017:204).

$$
w j+w_{j}+w_{j}+\ldots+w_{j}=1
$$

Eşitlik (5)'den yararlanarak hesaplanan entropi kriter ağırlıkları Tablo 10 'da yer almıştır. 
Tablo 10: Entropi Kriter A ğırlıklarının $\left(\mathrm{w}_{\mathrm{j}}\right)$ Hesaplanması

\begin{tabular}{|c|c|c|c|c|c|c|c|c|c|c|c|c|}
\hline & $\mathbf{A}_{1}$ & $\mathbf{A}_{2}$ & $\mathbf{A}_{3}$ & $\mathbf{A}_{4}$ & $\mathbf{A}_{5}$ & $\mathbf{A}_{6}$ & $\mathbf{A}_{7}$ & $\mathbf{A}_{8}$ & $\mathbf{A}_{9}$ & $\mathbf{A}_{10}$ & $\mathbf{A}_{11}$ & $\mathbf{A}_{12}$ \\
\hline In (m) & $\begin{array}{c}0,33 \\
96\end{array}$ & & & & & & & & & & & \\
\hline ej & $\begin{array}{c}0,99 \\
65\end{array}$ & $\begin{array}{c}0,99 \\
53\end{array}$ & $\begin{array}{c}0,82 \\
14\end{array}$ & $\begin{array}{c}0,91 \\
44\end{array}$ & $\begin{array}{c}0,99 \\
69\end{array}$ & $\begin{array}{c}0,97 \\
96\end{array}$ & $\begin{array}{c}0,98 \\
39\end{array}$ & $\begin{array}{c}0,99 \\
30\end{array}$ & $\begin{array}{c}0,99 \\
33\end{array}$ & $\begin{array}{c}0,97 \\
90\end{array}$ & $\begin{array}{c}0,94 \\
77\end{array}$ & $\begin{array}{c}0,68 \\
92\end{array}$ \\
\hline $\mathrm{d} j$ & $\begin{array}{c}0,00 \\
35\end{array}$ & $\begin{array}{c}0,00 \\
47 \\
\end{array}$ & $\begin{array}{c}0,17 \\
86\end{array}$ & $\begin{array}{c}0,08 \\
56\end{array}$ & $\begin{array}{c}0,00 \\
31\end{array}$ & $\begin{array}{c}0,02 \\
04 \\
\end{array}$ & $\begin{array}{c}0,01 \\
61 \\
\end{array}$ & $\begin{array}{c}0,00 \\
70 \\
\end{array}$ & $\begin{array}{c}0,00 \\
67 \\
\end{array}$ & $\begin{array}{c}0,02 \\
10 \\
\end{array}$ & $\begin{array}{c}0,05 \\
23\end{array}$ & $\begin{array}{c}0,31 \\
08\end{array}$ \\
\hline $\mathbf{W} \boldsymbol{j}$ & $\begin{array}{c}0,00 \\
49\end{array}$ & $\begin{array}{c}0,00 \\
67\end{array}$ & $\begin{array}{c}0,25 \\
16\end{array}$ & $\begin{array}{c}0,12 \\
06\end{array}$ & $\begin{array}{c}0,00 \\
43\end{array}$ & $\begin{array}{c}0,02 \\
87\end{array}$ & $\begin{array}{c}\mathbf{0 , 0 2} \\
27\end{array}$ & $\begin{array}{c}0,00 \\
99\end{array}$ & $\begin{array}{c}0,00 \\
94\end{array}$ & $\begin{array}{c}0,02 \\
95\end{array}$ & $\begin{array}{c}\mathbf{0 , 0 7} \\
36\end{array}$ & $\begin{array}{c}0,43 \\
79\end{array}$ \\
\hline $\begin{array}{c}\text { Ağırlık } \\
\text { Sıralaması }\end{array}$ & 11 & 10 & 2 & 3 & 12 & 6 & 7 & 8 & 9 & 5 & 4 & 1 \\
\hline
\end{tabular}

\section{EDAS Yöntemi}

İlk olarak Keshavarz-Ghorabaee vd. tarafından çok kriterli envanter sınıflaması problemleri için Ortalama Çözüm Uzaklığına Dayalı Değerlendirme (Evaluation Based on Distance from Average SolutionEDAS) yöntemidir. Yöntemde, alternatiflerin her bir kritere göre ortalama çözüm (average solution $-\mathrm{V}_{j}$ ) uzaklıkları hesaplanarak en iyi alternatif bulunmaktadır. Ancak EDAS yönteminde en iyi ve en kötü değerlerin hesaplanmasına gerek yoktur. Kabul edilebilirliğine dair iki ölçü bulunmaktadır. Bunlardan birincisi, ortalamadan pozitif uzaklık (positive distance from average $-\mathrm{PDA}_{i j}$ ) ve ikincisi ortalamadan negatif uzaklik (negative distance from average- $\mathrm{NDA}_{i j}$ )'tır. Alternatiflerin değerlendirilmesi, daha yüksek PDA değerlerine ve daha düşük NDA değerlerine göre yapılmakta, daha yüksek PDA değerleri ve / veya daha düşük NDA değerleri, çözümün (alternatif) ortalama çözümden daha iyi olduğunu göstermektedir (Keshavarz-Ghorabaee vd.,2015:438-439). Yöntemi geliştirenler, EDAS yöntemini diğer çok kriterli karar verme yöntemleri ile karşılaştırmışlar, geçerliliğini test etmişler ve birçok problemin çözümünde başarılı olarak uygulandığını görmüşlerdir (Özbek ve Engür, 2019:8).

EDAS yönteminin uygulama adımları aşağıda gösterilmiştir. (Çakır, 2018:1913-1914; Özar1 ve Kandemir, 2019:467-470; Ulutaş, 2018:172177) 
Adım 1: Karar matrisinin oluşturulması:

Karar matrisi Entropi Adım 1'de yer alan Tablo 6 ile aynıdır.

Adım 2: Tüm kriterlere göre ortalama çözüm $\left(A V_{j}\right)$ belirlenir: Bütün kriterlerin $\left(A_{1}, A_{2}, \ldots, A_{12}\right)$ değerlerinin ortalaması alınarak ortalama değer matrisi oluşturulur. Karar matrisinde (Tablo 5) her bir kriterin ortalamasinı oluşturan ortalama değerler $\left(A V_{j}\right)$ aşağıda yer alan Tablo 11 'de verilmiştir.

Tablo 11: Ortalama Değerler $\left(A V_{j}\right)$

\begin{tabular}{crrrrrrrrrrrr}
\hline & \multicolumn{1}{c}{$\mathbf{A}_{\mathbf{1}}$} & \multicolumn{1}{c}{$\mathbf{A}_{\mathbf{2}}$} & \multicolumn{1}{c}{$\mathbf{A}_{\mathbf{3}}$} & \multicolumn{1}{c}{$\mathbf{A}_{\mathbf{4}}$} & \multicolumn{1}{c}{$\mathbf{A}_{\mathbf{5}}$} & \multicolumn{1}{c}{$\mathbf{A}_{\mathbf{6}}$} & \multicolumn{1}{c}{$\mathbf{A}_{\mathbf{7}}$} & \multicolumn{1}{c}{$\mathbf{A}_{\mathbf{8}}$} & \multicolumn{1}{c}{$\mathbf{A}_{\mathbf{9}}$} & \multicolumn{1}{c}{$\mathbf{A}_{\mathbf{1 0}}$} & \multicolumn{1}{c}{$\mathbf{A}_{\mathbf{1 1}}$} & $\mathbf{A}_{\mathbf{1 2}}$ \\
\hline ORTALA & 19,3 & 18,0 & 15,7 & 5,62 & 89,5 & 1,38 & 12,3 & 61,4 & 59,4 & 29,9 & 45,4 & 3,24 \\
MA & 82 & 32 & 37 & 7 & 91 & 5 & 05 & 06 & 71 & 27 & 08 & 7 \\
\hline
\end{tabular}

Adım 3: Ortalamadan pozitif uzaklık matrisi (PDA) ve ortalamadan negatif uzaklık matrisi (NDA)'nin oluşturulmasi: $P D A=[P D A i j] m \times n$ ve $N D A=[N D A i j] m \times n$ matrislerinin boyutları karar matrisinin boyutu ile aynıdır. Her bir kriter için hesaplanır. Kriterlerin fayda esaslı (Mak) ya da maliyet esaslı (Min) olmasına göre bu değerlerin hesaplanması değişiklik gösterir.

Eğer kriter fayda esaslı ise aşağıdaki Eşitlik (6) uygulanır.

$$
\begin{array}{ccc}
\mathrm{PDA} i & \frac{\max (0,(\mathrm{Y} i j-\mathrm{AV} j))}{A V j} & \mathrm{NDA} i \\
j= & j= & \frac{\max (0,(\mathrm{AV} i j-\mathrm{Y} i j))}{A V j}
\end{array}
$$

Eğer kriter maliyet esaslı ise aşağıdaki Eşitlik (7) uygulanır.

$$
\underset{\mathrm{PDA} i}{j=} \frac{\max (0,(\mathrm{AV} i j-\mathrm{Y} j))}{A V j} \quad \mathrm{NDA} i \frac{\max (0,(\mathrm{Y} i j-\mathrm{AV} i j))}{A V j}
$$

Eşitliklerde gösterilen PDA $i j$ ve NDA $i j$ sırasıyla $i$. alternatifin $j$. kriterdeki ortalama çözüme olan pozitif ve negatif uzaklıkları göstermektedir. Tablo 12'de 2018 yılı için Eşitlik (6) yardımı ile elde edilen ortalamadan pozitif uzaklık matrisi (PDA) ve her bir kriterin entropi yöntemi ile tespit edilen ağırlıkları (wj) ile çarpılması sonucu bulunan değerlerin toplanması ile elde edilen $S P i$ değerleri yer almaktadır. 
Türkiye ve Seçilmiş Ülkelerde Mevduat Kabul Eden Kuruluşların Finansal Sağlamlık

Göstergelerinin Entropi ve Edas Yöntemi ile Değerlendirilmesi

\section{Tablo 12: Ortalamadan Pozitif Uzaklık Matrisi $(P D A)$ ve Ağırlıklı $S P_{i}$ Değerinin Bulunmas1}

\begin{tabular}{|c|c|c|c|c|c|c|c|c|c|c|c|c|c|}
\hline & MAK & MAK & MIN & MIN & MAK & MAK & MAK & MAK & MAK & MIN & MAK & MAK & \\
\hline & $\mathbf{A}_{1}$ & $\mathbf{A}_{\mathbf{2}}$ & $\mathbf{A}_{3}$ & $\mathbf{A}_{4}$ & $\mathbf{A}_{5}$ & $\mathbf{A}_{6}$ & $\mathbf{A}_{7}$ & $\mathbf{A}_{8}$ & $\mathbf{A}_{9}$ & $\mathbf{A}_{10}$ & $\mathbf{A}_{11}$ & $A_{12}$ & $\mathrm{SP} i$ \\
\hline Arnavutluk & 0,0000 & 0,0000 & 0,0116 & 0,0000 & 0,0000 & 0,0000 & 0,0012 & 0,0063 & 0,0000 & 0,0000 & 0,0000 & 0,0000 & 0,0192 \\
\hline $\begin{array}{c}\text { Bosna } \\
\text { Hersek }\end{array}$ & 0,0000 & 0,0000 & 0,0574 & 0,0000 & 0,0004 & 0,0000 & 0,0000 & 0,0000 & 0,0000 & 0,0000 & 0,0000 & 0,1358 & 0,1936 \\
\hline Bulgaristan & 0,0003 & 0,0005 & 0,0000 & 0,0000 & 0,0002 & 0,0042 & 0,0000 & 0,0006 & 0,0023 & 0,0000 & 0,0000 & 0,4082 & 0,4164 \\
\hline Hirvatistan & 0,0009 & 0,0014 & 0,0454 & 0,0000 & 0,0004 & 0,0003 & 0,0000 & 0,0000 & 0,0008 & 0,0044 & 0,0027 & 0,0000 & 0,0562 \\
\hline Kıbris & 0,0000 & 0,0000 & 0,0000 & 0,0000 & 0,0000 & 0,0000 & 0,0000 & 0,0000 & 0,0012 & 0,0070 & 0,0027 & 0,4244 & 0,4353 \\
\hline $\begin{array}{c}\text { Çek } \\
\text { Cumhuriyeti }\end{array}$ & 0,0000 & 0,0000 & 0,0692 & 0,0533 & 0,0000 & 0,0000 & 0,0093 & 0,0006 & 0,0020 & 0,0000 & 0,0000 & 0,2976 & 0,4320 \\
\hline Estonya & 0,0023 & 0,0037 & 0,2212 & 0,1109 & 0,0004 & 0,0077 & 0,0018 & 0,0000 & 0,0019 & 0,0000 & 0,0000 & 0,0000 & 0,3499 \\
\hline Macaristan & 0,0000 & 0,0000 & 0,2007 & 0,0678 & 0,0001 & 0,0116 & 0,0131 & 0,0000 & 0,0000 & 0,0000 & 0,0000 & 0,2963 & 0,5895 \\
\hline Kosova & 0,0000 & 0,0000 & 0,2285 & 0,0665 & 0,0002 & 0,0192 & 0,0111 & 0,0027 & 0,0018 & 0,0000 & 0,0000 & 0,0000 & 0,3300 \\
\hline Letonya & 0,0007 & 0,0008 & 0,0000 & 0,0073 & 0,0000 & 0,0000 & 0,0000 & 0,0000 & 0,0000 & 0,0001 & 0,0000 & 0,3152 & 0,3241 \\
\hline Litvanya & 0,0000 & 0,0002 & 0,0000 & 0,0720 & 0,0005 & 0,0026 & 0,0083 & 0,0000 & 0,0009 & 0,0000 & 0,0000 & 0,4352 & 0,5195 \\
\hline Malta & 0,0000 & 0,0000 & 0,0000 & 0,0488 & 0,0000 & 0,0000 & 0,0000 & 0,0010 & 0,0000 & 0,0000 & 0,0000 & 0,4366 & 0,4864 \\
\hline Karadağ & 0,0000 & 0,0000 & 0,1137 & 0,0000 & 0,0003 & 0,0000 & 0,0000 & 0,0000 & 0,0000 & 0,0000 & 0,0000 & 0,4352 & 0,5492 \\
\hline Polonya & 0,0000 & 0,0000 & 0,1010 & 0,0381 & 0,0003 & 0,0000 & 0,0000 & 0,0002 & 0,0000 & 0,0000 & 0,0000 & 0,4204 & 0,5600 \\
\hline Romanya & 0,0003 & 0,0002 & 0,0550 & 0,0144 & 0,0001 & 0,0035 & 0,0042 & 0,0006 & 0,0010 & 0,0224 & 0,2031 & 0,3489 & $\mathbf{0 , 6 5 3 7}$ \\
\hline Sirbistan & 0,0007 & 0,0011 & 0,0965 & 0,0000 & 0,0000 & 0,0169 & 0,0000 & 0,0000 & 0,0002 & 0,0203 & 0,0000 & 0,0000 & 0,1358 \\
\hline Slovakya & 0,0000 & 0,0000 & 0,1409 & 0,0546 & 0,0002 & 0,0000 & 0,0000 & 0,0018 & 0,0000 & 0,0000 & 0,0000 & 0,3341 & 0,5316 \\
\hline Slovenya & 0,0000 & 0,0000 & 0,2083 & 0,0812 & 0,0000 & 0,0011 & 0,0000 & 0,0000 & 0,0000 & 0,0023 & 0,0090 & 0,0000 & 0,3019 \\
\hline Türkiye & 0,0000 & 0,0000 & 0,1568 & 0,0416 & 0,0004 & 0,0082 & 0,0086 & 0,0010 & 0,0028 & 0,0169 & 0,0302 & 0,2329 & 0,4993 \\
\hline
\end{tabular}


Tablo 13 'te 2018 yılı için Eşitlik (7) yardımı ile elde edilen ortalamadan negatif uzakl1k matrisi $(N D A)$ ve her bir kriterin entropi yöntemi ile tespit edilen ağırlıkları $(w j)$ ile çarpılması sonucu bulunan değerlerin toplanması ile elde edilen $S N i$ değerleri yer almaktadır.

Tablo 13: Ortalamadan Negatif Uzaklık Matrisi $(N D A)$ ve Ağırlıklı $S N_{i}$ Değerinin Bulunmas1

\begin{tabular}{|c|c|c|c|c|c|c|c|c|c|c|c|c|c|}
\hline & MAK & МАК & MIN & MIN & МАК & MAK & МАK & МАК & МАK & MIN & МАК & MAK & \\
\hline & $\mathbf{A}_{1}$ & $\mathbf{A}_{2}$ & $\mathbf{A}_{3}$ & $\mathbf{A}_{4}$ & $A_{5}$ & $A_{6}$ & & $\mathbf{A}_{8}$ & A9 & $\mathbf{A}_{10}$ & & $\mathbf{A}_{12}$ & $\mathrm{SN} i$ \\
\hline & 003 & 0,0004 & 0000 & & 0002 & 0039 & 0,0000 & 0,0000 & 0,0029 & 0,0150 & 0,0413 & 0,6114 & 0,7923 \\
\hline & & 0,0006 & 0,0000 & 0,0674 &, 0000 & 0,0015 & 0,0049 & 0,0004 & 0,0023 & 0,0002 & & 0,0000 & 0,0790 \\
\hline Bulgaristan & 0000 & 0,0000 & 0,1995 & 0,0466 & 0,0000 & 0,0000 & 0,0009 & 0,0000 & 0,0000 & 0,0010 & 0,0156 & 0,0000 & 0,2637 \\
\hline & 0000 & 0,0000 & 0,0000 & & 0000 & 0,0000 & 0,0050 & 0,0008 & 0,0000 & 0,0000 & 0,0000 & 0,2459 & 0,3391 \\
\hline & & 0,0006 & & & & & & 0,0016 & 0,0000 & 0,0000 & 0,0000 & 0,0000 & 1,6880 \\
\hline $\begin{array}{l}\text { Ç } \\
\text { C }\end{array}$ & & & & & 0,0000 & 0,0060 & 0,0000 & 0,0000 & 0,0000 & & 0,0250 & 0,0000 & 0,0459 \\
\hline & 0,0000 & 0,0000 & 0,0000 & 0,0000 & 0,0000 & 0,0000 & 0,0000 & 0,0029 & 0,0000 & 0,0073 & 0,0196 & 2,7464 & 2,7762 \\
\hline & 0,0002 & 0,0005 & 0,0000 & 0,0000 & 0,0000 & 0,0000 & 0,0000 & 0,0022 & 0,0017 & 0,0029 & 0,0061 & 0,0000 & 0,0136 \\
\hline & 0,0006 & 0,0010 & 0,0000 & 0,0000 & 0,0000 & 0,0000 & 0,0000 & 0,0000 & 0,0000 & 0,0009 & 0,0088 & 0,0800 & 0,0913 \\
\hline & 0,0000 & 0,0000 & 0,0958 & 0,0000 & 0,0002 & 0,0042 & 0,0051 & 0,0024 & 0,0013 & 0,0000 & 0,0134 & 0,0000 & 0,1225 \\
\hline & 0,0002 & 0,0000 & 0,0354 & 0,0000 & 0,0000 & 0,0000 & 0,0000 & 0,0011 & 0,0000 & 0,0043 & 0,0228 & 0,0000 & 0,0639 \\
\hline & 0,0003 & 0,0008 & 0,0167 & 0,0000 & 0,0005 & 0,0140 & 0,0072 & 0,0000 & 0,0000 & 0,0016 & 0,0129 & 0,0000 & 0,0540 \\
\hline & 0,0010 & 0,0014 & 0,0000 & 0,0386 & 0,0000 & 0,0077 & 0,0070 & 0,0009 & 0,0027 & 0,0073 & 0,0162 & 0,0000 & $\mathbf{0 , 0 8 2 7}$ \\
\hline & 0,0003 & 0,0006 & 0,0000 & 0,0000 & 0,0000 & 0,0140 & 0,0088 & 0,0000 & 0,0001 & 0,0154 & 0,0328 & 0,0000 & 0,0719 \\
\hline & 0,0000 & 0,0000 & 0,0000 & 0,0000 & 0,0000 & 0,0000 & 0,0000 & 0,0000 & 0,0000 & 0,0000 & 0,0000 & 0,0000 & 0,0000 \\
\hline & 0,0000 & 0,0000 & 0,0000 & & & 0,0000 & & 0,0014 & 0,0000 & 0,0000 & 0,0157 & & 0,1646 \\
\hline & 0,0002 & 0,0005 & 0,0000 & & 0,0000 & 0,0067 & 0,0041 & 0,0000 & 0,0000 & 0,0029 & 0,0163 & 0,0000 & 0,0306 \\
\hline & & & 0,0000 & & 0,0001 & 0,0000 & & 0,0013 & 0,0038 & 0,0000 & 0,0000 & 0,6950 & 0,7026 \\
\hline Türkiye & 0,0005 & 0,0015 & 0,0000 & 0,0000 & 0,0000 & 0,0000 & 0,0000 & 0,0000 & 0,0000 & 0,0000 & 0,0000 & 0,0000 & 0,0020 \\
\hline
\end{tabular}

Adım 4: Bütün alternatiflerin $S P i$ ve $S N i$ değerleri hesaplanır. $S P i$, $i$. alternatifin ağırlıklı toplam pozitif değerini ve $S N i$ ise $i$. alternatifin ağırlıklı toplam negatif değeri olarak tanımlanır ve aşağıdaki gibi hesaplanır. Adım 4 kapsamında ve Eşitlik (6) ile hesaplanan $S P i$ değerleri Tablo 12'de ve Eşitlik (7) ile hesaplanan SNi değerleri Tablo 13'te, Eşitlik (8) yardımı ile kriter ağırlıkları (wj) ile çarpılarak tablolarda yer almıştır. 


$$
S P i=\sum_{j=1}^{m} w_{j \times P D A i j}, \quad S N i=\sum_{j=1}^{m} w_{j} \times N D A i j
$$

Adım 5: Bu adımda 4. adımda tüm alternatifler için hesaplanan $S P i$ ve $S N i$ değerleri aşağıdaki Eşitlik (9) ile normalize edilir.

$$
N S P i=\frac{S P i}{\operatorname{maxi}(S P i)}, \quad N S N i=\frac{S N i}{\operatorname{maxi}(S N i)}
$$

Bir başka ifade ile $N S P i$ ve $N S N i$ değerleri sırasıyla i. alternatifin normalize edilmiş ağırlıklı toplam pozitif ve negatif değerlerini gösterir. (Adım 5 kapsamında hesaplanan NSPi ve NSNi değerleri Tablo 14'te yer almıştır.)

Adım 6: Bu adımda her alternatif için değerlendirme skorları ( $A S i)$, Eşitlik (10) yardımıyla hesaplanır. Bu değer her zaman 0 ile 1 arasında değer alır ve en büyük $A S i$ değerine sahip alternatif en iyi alternatif olarak belirlenir.

$$
A S i=\stackrel{1}{2}^{\frac{1}{2}}\left(N S P_{i}+N S N_{i}\right)
$$


Tablo 14: $N S P_{i}, N S N_{i}$ ve $A S_{i}$ Değerlendirme Skorları ve Siralama

\begin{tabular}{|l|c|c|c|c|c|c|}
\cline { 2 - 7 } \multicolumn{1}{c|}{} & $\mathbf{S P}_{\boldsymbol{i}}$ & $\mathbf{S N}_{\boldsymbol{i}}$ & $\mathbf{N S P}_{\boldsymbol{i}}$ & $\mathbf{N S N}_{\boldsymbol{i}}$ & $\mathbf{A S}_{\boldsymbol{i}}$ & SIRALAMA \\
\hline Arnavutluk & 0,0192 & 0,7923 & 0,0294 & 0,7146 & 0,3720 & $\mathbf{1 8}$ \\
\hline Bosna Hersek & 0,1936 & 0,0790 & 0,2962 & 0,9715 & 0,6339 & $\mathbf{1 3}$ \\
\hline Bulgaristan & 0,4164 & 0,2637 & 0,6369 & 0,9050 & 0,7710 & $\mathbf{1 0}$ \\
\hline Hırvatistan & 0,0562 & 0,3391 & 0,0860 & 0,8779 & 0,4819 & $\mathbf{1 7}$ \\
\hline Kıbris & 0,4353 & 1,6880 & 0,6659 & 0,3920 & 0,5289 & $\mathbf{1 6}$ \\
\hline Çek Cumhuriyeti & 0,4320 & 0,0459 & 0,6608 & 0,9835 & 0,8222 & $\mathbf{9}$ \\
\hline Estonya & 0,3499 & 2,7762 & 0,5353 & 0,0000 & 0,2676 & $\mathbf{1 9}$ \\
\hline Macaristan & 0,5895 & 0,0136 & 0,9018 & 0,9951 & 0,9485 & $\mathbf{2}$ \\
\hline Kosova & 0,3300 & 0,0913 & 0,5048 & 0,9671 & 0,7360 & $\mathbf{1 1}$ \\
\hline Letonya & 0,3241 & 0,1225 & 0,4957 & 0,9559 & 0,7258 & $\mathbf{1 2}$ \\
\hline Litvanya & 0,5195 & 0,0639 & 0,7947 & 0,9770 & 0,8859 & $\mathbf{6}$ \\
\hline Malta & 0,4864 & 0,0540 & 0,7440 & 0,9806 & 0,8623 & $\mathbf{8}$ \\
\hline Karadağ & 0,5492 & 0,0827 & 0,8400 & 0,9702 & 0,9051 & $\mathbf{4}$ \\
\hline Polonya & 0,5600 & 0,0719 & 0,8566 & 0,9741 & 0,9153 & $\mathbf{3}$ \\
\hline Romanya & 0,6537 & 0,0000 & 1,0000 & 1,0000 & 1,0000 & $\mathbf{1}$ \\
\hline Sirbistan & 0,1358 & 0,1646 & 0,2077 & 0,9407 & 0,5742 & $\mathbf{1 5}$ \\
\hline Slovakya & 0,5316 & 0,0306 & 0,8132 & 0,9890 & 0,9011 & $\mathbf{5}$ \\
\hline Slovenya & 0,3019 & 0,7026 & 0,4618 & 0,7469 & 0,6044 & $\mathbf{1 4}$ \\
\hline Türkiye & 0,4993 & 0,0020 & 0,7638 & 0,9993 & 0,8815 & $\mathbf{7}$ \\
\hline MAKSiMUM & $\mathbf{0 , 6 5 3 7}$ & $\mathbf{2 , 7 7 6 2}$ & & & &
\end{tabular}

\section{ARAŞTIRMA BULGULARI}

Şekil 1'de ülkelerin ASi değerlerine göre sıralaması yer almaktadır. 12 Temel Finansal Sağlamlık göstergesine dayanarak, seçilen ülkelerin 2018 yılı verilerinin EDAS yöntemi ile yapılan performans sıralamasına göre; Romanya'da faaliyet gösteren mevduat kabul eden kuruluşlar (bankalar) performans sıralamasında 1.sırada yer almış, Türkiye 7.sırada, 19. ve son sirada ise Estonya yer almıştır. 
Şekil 1: Ülkelerin Performans Siralaması 2018

\begin{tabular}{|c|c|c|c|c|}
\hline Ülkeler & $\mathbf{A S i}$ & Siralama & \multirow{19}{*}{$\begin{array}{r}20 \\
18 \\
16 \\
14 \\
12 \\
10 \\
8 \\
6 \\
4 \\
2 \\
0\end{array}$} & Ülkelerin Performans Sıralaması-2018 \\
\hline Romanya & 1,0000 & 1 & & 18 \\
\hline Macaristan & 0,9485 & 2 & & \\
\hline Polonya & 0,9153 & 3 & & \\
\hline Karadağ & 0,9051 & 4 & & \\
\hline Slovakya & 0,9011 & 5 & & \\
\hline Litvanya & 0,8859 & 6 & & \\
\hline Türkiye & 0,8815 & 7 & & $9^{10}$ \\
\hline Malta & 0,8623 & 8 & & 7 \\
\hline $\begin{array}{l}\text { Çek } \\
\text { Cumhuriyeti }\end{array}$ & 0,8222 & 9 & & 6 \\
\hline Bulgaristan & 0,7710 & 10 & & 3 \\
\hline Kosova & 0,7360 & 11 & & 1 \\
\hline Letonya & 0,7258 & 12 & & \\
\hline Bosna Hersek & 0,6339 & 13 & & $\approx \pi$, \\
\hline Slovenya & 0,6044 & 14 & & 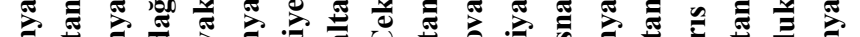 \\
\hline Surbistan & 0,5742 & 15 & & 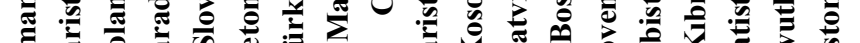 \\
\hline Kıbris & 0,5289 & 16 & & 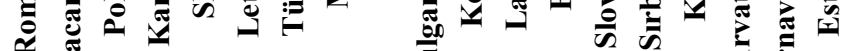 \\
\hline Hurvatistan & 0,4819 & 17 & & 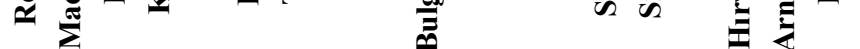 \\
\hline Arnavutluk & 0,3720 & 18 & & \\
\hline Estonya & 0,2676 & 19 & & \\
\hline
\end{tabular}

Tablo 15'te, ülkelerin performans siralamasında dikkate alınan 12 temel finansal sağlamlık göstergelerin (kriterler), her birindeki siralaması yer almaktadır. Romanya'nın 3 kriterde ilk 5'te, 9 kriterde ilk 10'da yer aldığ 1 ve 19 Ülke arasında en fazla 12. Siraya kadar düştüğü görülmektedir. Türkiye'nin ise 8 kriterde ilk 5'te, 9 kriterde ilk 10'da yer aldığ $1, A_{1}$ ve $A_{2}$ kriterlerinde de surasiyla 17 . ve 19 . Surada yer aldı̆̆ görülmektedir. Türkiye'nin siralamasında etkili olan $\mathrm{A}_{12}$ kriteri olup, bu kriterin ağırlığı \%43’tür ve Türkiye bu kriterde 12.sırada yer almıştır.

İlk 10 içerisinde yer alan ülkelerden, 8 ülke halen $A B$ 'ye üyesi ülkeler olup, 4.sıara yer alan Kosova ile 7. sirada yer alan Türkiye aday ülke konumundadır. Diğer aday ülkeler Arnavutluk 18. ve Sirbistan 15. Sirada yer almıştır. Potansiyel aday ülkeler Bosna Hersek 13. ve Kosova da 11. sirada yer almıştır. 
Suralama ile ülkelerin kriterlerdeki sıralaması arasındaki korelasyon incelendiğinde, sıralama ile $\mathrm{A}_{12}$ kriteri arasındaki korelasyon \%64 çıkmış olup, en yüksek korelasyon bu kriterde olmuştur.

Tablo 15: Ülkelerin 12 Göstergedeki (Kriter) Performans Siralamas1

\begin{tabular}{|c|c|c|c|c|c|c|c|c|c|c|c|c|c|}
\hline Ağırlık Sırası & & 11 & 10 & 2 & 3 & 12 & 6 & 7 & 8 & 9 & 5 & 4 & 1 \\
\hline Ağırlık (w) & $\underline{\Xi}$ & 0,0049 & 0,0067 & 0,2516 & 0,1206 & $\mathbf{0 , 0 0 4 3}$ & $\mathbf{0 , 0 2 8 7}$ & $\mathbf{0 , 0 2 2 7}$ & 0,0099 & 0,0094 & 0,0295 & $\mathbf{0 , 0 7 3 6}$ & 0,4379 \\
\hline Fayda / Maliyet & $\stackrel{5}{=}$ & MAK & MAK & MIN & MIN & MAK & MAK & MAK & MAK & MIN & MAK & MAK & MIN \\
\hline Kriter & & $\mathbf{A}_{1}$ & $\mathbf{A}_{\mathbf{2}}$ & $\mathbf{A}_{3}$ & $\mathbf{A}_{4}$ & $\mathbf{A}_{5}$ & $\mathbf{A}_{6}$ & $\mathbf{A}_{7}$ & A8 & A9 & $\mathbf{A}_{10}$ & $\mathbf{A}_{11}$ & $\mathbf{A}_{12}$ \\
\hline Arnavutluk & 18 & 12 & 10 & 14 & 18 & 15 & 12 & 8 & 1 & 18 & 18 & 19 & 17 \\
\hline Bosna Hersek & 13 & 15 & 13 & 11 & 16 & 2 & 11 & 13 & 10 & 16 & 8 & 6 & 13 \\
\hline Bulgaristan & 10 & 6 & 5 & 18 & 15 & 8 & 6 & 9 & 7 & 2 & 10 & 11 & 6 \\
\hline Hurvatistan & 17 & 2 & 2 & 13 & 17 & 5 & 10 & 14 & 11 & 9 & 5 & 5 & 16 \\
\hline Kıbris & 16 & 16 & 14 & 19 & 19 & 18 & 19 & 19 & 16 & 6 & 4 & 4 & 4 \\
\hline Çek Cumhuriyeti & 9 & 11 & 8 & 10 & 7 & 13 & 14 & 3 & 8 & 3 & 17 & 17 & 10 \\
\hline Estonya & 19 & 1 & 1 & 2 & 1 & 4 & 5 & 7 & 19 & 4 & 16 & 15 & 19 \\
\hline Macaristan & 2 & 8 & 12 & 4 & 4 & 11 & 3 & 1 & 17 & 15 & 13 & 7 & 11 \\
\hline Kosova & 11 & 18 & 17 & 1 & 5 & 9 & 1 & 2 & 2 & 5 & 9 & 8 & 14 \\
\hline Letonya & 12 & 3 & 4 & 17 & 12 & 16 & 13 & 15 & 18 & 14 & 7 & 10 & 9 \\
\hline Litvanya & 6 & 7 & 7 & 16 & 3 & 1 & 8 & 5 & 13 & 8 & 14 & 16 & 2 \\
\hline Malta & 8 & 13 & 16 & 15 & 8 & 17 & 18 & 17 & 4 & 11 & 11 & 9 & 1 \\
\hline Karadağ & 4 & 19 & 18 & 7 & 14 & 7 & 16 & 16 & 12 & 17 & 15 & 13 & 2 \\
\hline Polonya & 3 & 10 & 15 & 8 & 10 & 6 & 17 & 18 & 9 & 13 & 19 & 18 & 5 \\
\hline Romanya & 2 & 5 & 6 & 12 & 11 & 12 & 7 & 6 & 6 & 7 & 1 & 1 & 7 \\
\hline Sirbistan & 15 & 4 & 3 & 9 & 13 & 19 & 2 & 11 & 15 & 10 & 2 & 12 & 15 \\
\hline Slovakya & 5 & 9 & 11 & 6 & 6 & 10 & 15 & 12 & 3 & 12 & 12 & 14 & 8 \\
\hline Slovenya & 14 & 14 & 9 & 3 & 2 & 14 & 9 & 10 & 14 & 19 & 6 & 3 & 18 \\
\hline Türkiye & 7 & 17 & 19 & 5 & 9 & 3 & 4 & 4 & 5 & 1 & 3 & 2 & 12 \\
\hline
\end{tabular}

\section{SONUÇ VE ÖNERILER}

Alternatiflerin değerlendirilmesinde kriterlerin ağırlıkları uzmanlarca ve karar vericiler tarafindan sübjektif olarak belirlenebilmekte olup, bu çalışmada ise kullanılan kriterlerin ağırlıkları Entropi Yöntemi kullanılarak belirlenmiştir. Entropi yönteminin güçlü yönü karar vericilerin değerlendirmelerine gerek duymadan alternatiflere ilişkin veriler kullanılarak objektif sonuçlar sağlamasıdır. Daha sonra karar 
matrisi ve belirlenen ağırlıklar, EDAS Yöntemi kullanılarak ülkelerin performans sıralamaları tespit edilmiştir.

Çalışma sonuçlarına göre Romanya'nın 3 kriterde ilk 5'te, 9 kriterde ilk 10 'da yer aldığ1 ve 19 ülke arasında en fazla 12. sıraya kadar düştüğü görülmektedir. Türkiye'nin ise 8 kriterde ilk 5 'te, 9 kriterde ilk 10'da yer aldığ $1, A_{1}$ ve $A_{2}$ kriterlerinde de sirasıyla 17. ve 19 . sirada yer aldığ görülmektedir. Türkiye'nin siralamasında etkili olan $A_{12}$ kriteri olup, bu kriterin ağırlığ $1 \% 43$ 'tür ve Türkiye bu kriterde 12.sırada yer almıştır.

İlk 10 içerisinde yer alan ülkelerden, 8 ülke halen AB'ye üyesi ülkeler olup, 4.sirada yer alan Kosova ile 7. sırada yer alan Türkiye aday ülke konumundadır. Diğer aday ülkeler Arnavutluk 18. ve Surbistan 15. sirada yer almıştır. Potansiyel aday ülkeler Bosna Hersek 13. ve Kosova da 11. sırada yer almıştır.

Türkiye'nin bu karşılaştırma ve sıralamalar dikkate alındığında, mevduat kabul eden kuruluşlara ilişkin 12 temel finansal gösterge açısından performans sıralaması, birçok Avrupa Birliği'ne üye, aday ve potansiyel aday ülkelere göre iyi düzeyde bulunmuştur. Ancak, farklı bir yıl verilerinin dikkate alınması ve/veya sübjektif olarak uzman görüşü ile ağırlık belirlenmesi durumunda farklı sıralamalar oluşabileceğini de belirtmek gerekir.

Finansal Sağlamlık Göstergelerine göre siralamanın yapıldığı bu çalışmada, Türkiye'nin bankacılık sektörünün daha üst sıralarda yer alabilmesi için Yabancı Para Net Açık Pozisyon / Sermaye $\left(\mathrm{A}_{12}\right)$ kriterinde, Sermaye Yeterliliği $\left(\mathrm{A}_{1}\right.$ ve $\left.\mathrm{A}_{2}\right)$ ve Takipteki Alacaklar / Toplam Krediler $\left(\mathrm{A}_{4}\right)$ kriterinde öncelikle iyileşme sağlaması, ayrıca diğer kriterlerdeki konumunu da koruması gerekmektedir.

2020 yılındaki gelişmeler, Korona virüsünün ülke ekonomileri ve finansal kesim üzerindeki negatif etkileri, bankacılık sektöründe kredi kullandırım imkânlarının arttırılması, sorunlu kredilerin zaten yüksek düzeyde bulunması, tüm ülkelerin verilerinde paralel olarak olumsuz gelişmeler olabileceği dikkate alınarak sektörün sağlamlığının korunmasına yönelik önlemler alınmalı ve yakından izlenmelidir. Çünkü reel sektördeki negatif 
gelişmelerin iyileştirilmesi, Merkez Bankası politikalarının ve hükümetlerin alacakları kararların etkin bir şekilde uygulanabilmesi için sağlam bir bankacılık sistemi gerekli ve önemlidir.

\section{KAYNAKÇA}

[1] Akbulut, O. (2019). Critic ve Edas Yöntemleri İle İş Bankası'nın 20092018 Yılları Arasındaki Performansının Analizi. Ekonomi Politika ve Finans Araştırmalarl Dergisi, 4 (2), 249-263. Doi: 10.30784/Epfad.594762

[2] Akçakanat, Ö, Aksoy, E, Teker, T . (2018). Critic ve Mdl Temelli Edas Yöntemi İle TR-61 Bölgesi Bankalarının Performans Değerlendirmesi. Süleyman Demirel Üniversitesi Sosyal Bilimler Enstitüsü Dergisi, 1 (32), 1-24., https://Dergipark.Org.Tr /Tr/Pub/Sbe/İssue/41366/488208

[3] Akkoç, S. \& Vatansever, K. (2013). Fuzzy Performance Evaluation With Ahp And Topsis Methods: Evidence From Turkish Banking Sector After The Global Financial Crisis. Eurasian Journal Of Business And Economics. 6. 53-74. Erişim Tarihi: 09.10.2019.

[4] Apan, M., A. Öztel ve M. İslamoğlu (2016). "An Assessment of the Paper Industry Firms Listed in Borsa Istanbul Using Entropy-Based MAUT Method." In M. H. BILLGIN, H. DANIS, E. DEMİ, \& U. CAN (Eds.), Financial Environment and Business Development: Pro-ceedings of the 16th Eurasia Business and Economics Society Conference. s. 15-28. Cham: Springer International Publishing.

[5] Asian Development Bank (2015). Financial Soundness Indicators For Financial Sector Stability A Tale Of Three Asian Countries, Https://Www.Adb.Org/Sites/Default/Files/ Publication/173687/Fsi-3Asian-Countries.Pdf, S. Vii, Erişim Tarihi: 18.05.2017

[6] Ayçin, E., (2019). Çok Kriterli Karar Verme: Bilgisayar Uygulamalı Çözümler, Nobel Yaymevi, Ankara

[7] Bakır, M. ve Atalık, Ö. (2018). Entropi ve Aras Yöntemleriyle Havayolu İşletmelerinde Hizmet Kalitesinin Değerlendirilmesi, Işsletme Araştırmaları Dergisi, 10/1 (2018), s.617-638 
[8] BDDK (2004). Bankacıllk Sektörü Değerlendirme Raporu (Ekim 2004), https://www.Bddk.Org.Tr/ Websitesi/Turkce/Raporlar/Finansal _Piyasalar_Raporlari/ 1497bankacilik_Sektoru_Degerlendirme_Raporu Ekim_\%202004.Pdf, Erişim: 11.11.2017.

[9] BDDK (2008). Finansal Piyasalar Raporu (Eylül 2008), https://www.Bddk.Org.Tr/Websitesi/Turkce/

Raporlar/Finansal_Piyasalar_Raporlari/

5835finansal_Piyasalar_Raporu_Eylül_2008.Pdf, Erişim: 01.11.2017.

[10] BDDK (2012). Finansal Piyasalar Raporu (Eylül 2012), https://www.bddk.org.tr/WebSitesi/turkce

/Raporlar/Finansal_Piyasalar_Raporlari/ 11531 fpreylul2012_281212.pdf, Erişim: 01.11.2017.

[11] Çakır, E., (2018), Bütünleşik Swara ve Edas Yöntemi Kullanarak Fitness Merkezlerinin Değerlendirilmesi: Örnek Bir Uygulama, Hitit Üniversitesi Sosyal Bilimler Enstitüsü Dergisi - Y1l 11, Say1 3, 2018, s.1907-1923

[12] Çat1, K., Es, A., \& Özevin, O. (2017). Futbol Takımlarının Finansal ve Sportif Etkinliklerinin Entropi ve TOPSIS Yöntemiyle Analiz Edilmesi: Avrupa'nın 5 Büyük Ligi ve Süper Lig Üzerine Bir Uygulama. International Journal of Management Economics \& Business, 13(1), 199222

[13] Demireli, E. \& Ural, M. \& Çalık, S. (2018). Kamu Bankalarında Performans Analizi: Entropi ve Waspas Yöntemleri İle Bir Uygulama, Pamukkale Üniversitesi Sosyal Bilimler Enstitüsü Dergisi, Sayı 31, Nisan 2018, 129-141,Erişim Tarihi: 09.10.2019

[14] Erol, I., S. Sencer ve R. Sarı (2011). "A New Fuzzy Fulti-Criteria Framework for Meas-uring Sustainability Performance of A Supply Chain", Ecological Economics, Volume: 70(6), s. 1088-1100. doi: http://dx.doi.org/10.1016/j.ecolecon.2011.01.001

[15] Eyüboğlu, K. (2016). Comparison The Financial Performances Of Developing Countries' Banking Sectors With Topsis Method. ODÜ Sosyal Bilimler Araştırmaları Dergisi. 220-236. Erişim Tarihi: 09.10.2019. 
[16] IMF (2017). The Financial Sector Assessment Program (Fsap), https://www.Imf.Org/En/

/Factsheets/Sheets/2016/08/01/16/14/Financial-Sector-Assessment-

Program, Erişim: 09.09.2019

[17] IMF (2006). Financial Soundness Indicators Compilation Guide, https://www.imf.org/external/pubs/ft/fsi/guide/2006/pdf/fsiFT.pdf,s.1,

Erişim: 09.09.2019

[18] IMF (2015). Financial Soundness Indicators And The Imf, https://www.Imf.Org/ External/Np/Sta/Fsi/Eng/Fsi.Htm, Erişim: 07.09.2019

[19] Isık, O . (2019). Türk Mevduat Bankacılığı Sektörünün Finansal Performanslarının Entropi Tabanlı Aras Yöntemi Kullanılarak Değerlendirilmesi. Finans Ekonomi Ve Sosyal Araştırmalar Dergisi (Fesa), 4 (1) , 90-99 . Do1: 10.29106/Fesa.533997

[20] Jose, San A., \& Georgiou, A. (2009). Financial Soundness indicators (FISs): Framework and Implementation. IFC Bulletin 31, Measuring Financial Innovation and Its Impact. Basel, BIS, s.277-282.

[21] Kandemir, A. ve Özarı, Ç. (2019). "Türkiye Avrupa Birliği Ekonomik Performans Karşılaştırması (2007-2017): Topsis-Edas Uygulamasi, Akademik Sosyal Araştırmalar Dergisi, Y11: 6, Sayı: 38, Haziran 2019, s. 456-479

[22] Kenger, Musat Deniz ve Organ, Arzu (2017) Banka Personel Seçiminin Çok Kriterli Karar Verme Yöntemlerinden Entropi Temelli Aras Yöntemi ile Değerlendirilmesi, Adnan Menderes Üniversitesi, Sosyal Bilimler Enstitüsü Dergisi, Cilt: 4, Sayı: 4, s.152-170

[23] Keshavarz Ghorabaee, M. Et Al (2015). Multi-Criteria Inventory Classification Using A New Method Of Evaluation Based On Distance From Average Solution (Edas), Informatica, 26(3):435-451

[24] Lindgren, C.J., Garcia, G. And Saal, M. (1996). Bank Soundness And Macroeconomic Policy, IMF, Washington DC, s.9.

[25] Lotfi, F.H., \& Fallahnejad, R. (2010). Imprecise Shannon's Entropy And Multi Attribute Decision Making. Entropy, 12, Erişim Tarihi: 09.10.2019. 
[26] Navajas, M. C. And Thegeya, A. (2013). Financial Soundness Indicators And Banking Crises, Imf Working Paper, No. Wp/13/263, https://www.Imf.Org/External/Pubs/Ft/Wp/2013/Wp13263.Pdf, Erişim Tarihi: 18.05.2017, s.3

[27] Özbek, A, Engür, M . (2019). Çok Kriterli Karar Verme Yöntemleriyle Öğrenci İşleri Otomasyon Seçimi. Afyon Kocatepe Üniversitesi İktisadi Ve İdari Bilimler Fakültesi Dergisi, 21 (1) , 1-18 . Doi: 10.33707/Akuiibfd.515581, Erişim Tarihi: 06.10.2019.

[28] Özden, Ü. H., (2009). Türkiye'deki Mevduat Bankalarının Performansları Çok Kriterli Karar Verme Yöntemleri ile Analiz, Ankara: Detay Yayınc1lık.

[29] Sundararajan, V., Enoch, Charles, San José, Armida and other. (2002). Financial Soundness Indicators:Analytical Aspects and Country Practices, IMF Occasional Paper, No:212,

[30] TCMB (2005). Finansal İstikrar Raporu (Ağustos 2005), Sayı:1, http://www.Tcmb.Gov.Tr/Wps/ Wcm/Connect/D790dd5c-091e-474aAf86-C2900c8cb67f/Fir_Tammetin.Pdf?Mod= Ajperes\&Cacheid=Rootworkspace-D790dd5c-091e-474a-Af86C2900c8cb67f-Krk7o05,Erişim Tarihi:01.11.2017.

[31] TCMB (2006). Finansal İstikrar Raporu (Haziran 2006), Sayı:2, http://www.Tcmb.Gov.Tr/Wps/ Wcm/Connect/6569b7d9-8b86-4a659dbf-868e2752e16b/Fir Tammetin2.Pdf?Mod $=$ Ajperes\&Cacheid=Rootworkspace-6569b7d9-8b86-4a65-9dbf868e2752e16b-Krk8ajk, Erişim Tarihi:01.11.2017

[32] TCMB (2010). Finansal İstikrar Raporu, http://www.Tcmb.Gov.Tr/Wps/Wcm/Connect/Ef8291f2-23a9-4de18a63-1059994436d4/

Fir_Tammetin10.Pdf?Mod=Ajperes\&Cacheid=Ef8291f2-23a9-4de18a63-1059994436d4, Erişim: 24.10.2017,

[33] TCMB (2014). Haziran 2014 Bülten, Sayı:34, http://www.Tcmb.Gov.Tr/Wps/Wcm/Connect/Tcmb+Tr/Tcmb+Tr/Main +Menu/Yayinlar/Tcmb+Bulten/Tcmb+Bulten, Erişim: 20.12.2017. 
[34] Tunca, M. Z., Ömürbek, N., Cömert, H. G., \& Aksoy, E. (2016). OPEC Ülkelerinin Performanslarının Çok Kriterli Karar Verme Yöntemlerinden Entropi ve Maut İle Değerlendirilmesi. Süleyman Demirel Üniversitesi Vizyoner Dergisi, 7(14), s.1-12.

[35] Ulutaş, Alptekin. (2018). ENTROPİ Tabanlı EDAS Yöntemi ile Lojistik Firmalarının Performans Analizi. Uluslararası Iktisadi ve İdari Incelemeler Dergisi, (23), s. 53-66.

[36] Vahdani, B., Hadipour, H., Sadaghiani, J.S. ve Amiri, M. (2010). Extension Of Vikor Method Based On Interval-Valued Fuzzy Sets, International Journal Of Advanced Manufacturing Technology, 47 (9-12) (2010),s. 1231-1239.

[37] Zavadskas, E. K. \& Turskis, Z. (2010). A New Additive Ratio Assessment (Aras) Method In Multicriteria Decision-Making, Ukio Technologinis Ir Ekonominis Vystymas, 16:2, 159-172, Doi: 10.3846/Tede.2010.10, Erişim Tarihi: 05.10.2019.

[38] Zhang X, Wang C, Li E, Xu C. (2014).Assessment model of ecoenvironmental vulnerability based on improved entropy weight method. Thescientificworldjournal.

[39] Zionts, S. (1979). Mcdm: If Not A Roman Numeral, Then What? Interfaces, 9(4) 94-101. Retrieved From http://www.Jstor.Org/Stable/25059779. Erişim Tarihi: 10.10.2019. 